Thomas M.J. Möllers*

\title{
Working with Legal Principles - demonstrated using Private Autonomy and Freedom of Contract as Examples
}

https://doi.org/10.1515/ercl-2018-1007

\begin{abstract}
Resolving legal problems at the national and European level, legal principles are of outstanding significance. However, it often remains unclear how to utilise these legal principles - which are partly not codified - in the specific legal solution. This article addresses two questions: How can we derive legal principles from the law if they have not been codified in the law? Moreover, how can we concretise legal principles? These two main issues will be illustrated on the basis of contractual freedom and particular legal institutes such as obligation to contract, price control, and frustration of contract. A last issue will be to tackle methodical difficulties posed by legal principles at the European level.
\end{abstract}

Résumé: Dans la solution de problèmes juridiques aux niveaux national et européen, les principes de droit ont une importance singulière. Cependant, il n'est pas toujours facile de savoir comment se servir concrètement de ces principes, qui ne sont pas toujours codifiés. Cet article tente de répondre à deux questions. Comment induire des principes du corps normatif alors qu'ils n'ont pas été codifiés ? Comment les rendre concrets ? Les réponses sont illustrées par référence à la liberté contractuelle et divers mécanismes comme l'obligation de contracter, le contrôle des prix ou la force majeure. Il restera alors à envisager les difficultés d'ordre méthodologique soulevées par les principes juridiques au niveau européen.

Zusammenfassung: Rechtsprinzipien haben auf nationaler und auf europäischer Ebene eine herausragende Bedeutung bei der Lösung von Rechtsproblemen. Wie diese Rechtsprinzipien, die zum Teil nicht kodifiziert sind, für die konkrete Rechtslösung herangezogen werden können, bleibt aber oft unklar. Dieser Artikel befasst sich mit zwei Fragen: Wie lassen sich Rechtsprinzipien aus dem Recht ableiten, wenn sie gesetzlich nicht niedergeschrieben sind? Zudem ist zu erörtern,

*Corresponding author: Professor Dr. Thomas M.J. Möllers, University of Augsburg,

E-Mail: thomas.moellers@jura.uni-augsburg.de 
wie Rechtsprinzipien konkretisiert werden können. Beide Hauptprobleme sollen anhand der Vertragsfreiheit und einzelner Rechtsinstitute wie Kontrahierungszwang, Preiskontrolle und Wegfall der Geschäftsgrundlage veranschaulicht werden. Abschließend soll methodologischen Schwierigkeiten mit Rechtsprinzipien auf europäischer Ebene nachgegangen werden.

\section{Introduction}

In our society, being principled is usually seen as a positive character trait. If a person remains true to his principles, he is considered to be strong-willed, sincere, and straightforward. In this respect, politicians and elected representatives are far too often prematurely assumed to put honest convictions aside in favour of securing power and influence or acting opportunistically in the interests of the strongest lobby at the time, and against the interests of the sovereign people. According to Gandhi, 'politics without principles' even represents one of his famous seven deadly sins of modern society. ${ }^{1}$ It is therefore hardly a new insight that both our man-made Basic Law for the Federal Republic of Germany (GG) and the ordinary law are permeated with numerous principles which are meant to ensure that the law is as straightforward as possible.

However, it is all the more astonishing that only a few of these legal principles are set out in positive law. For example, little is recorded in writing on the principle in the law of obligations of freedom of contract ${ }^{2}$ in the German Civil Code (BGB) as well as on the principle of contractual fidelity (pacta sunt servan$d a) .{ }^{3}$ However, the existence and applicability of these principles are not seriously disputed. Scholars assume unanimously that the BGB presupposes these princi-

1 Gandhi, 'Seven Social Sins’ Young India (22 October 1925 (no 43)) 361: 'politics without principles'.

2 The term is even referred to in the Motive zu dem Entwurfe eines Bürgerlichen Gesetzbuches für das Deutsche Reich (ie travaux preparatoire for the first draft of the German Civil Code) volume II (1896) 2: 'By virtue of the principle of freedom of contract, which governs the law of contractual obligations, the parties can determine their legal relationships and associations between themselves at their discretion with binding effect, insofar as there are no conflicting general or specific individual absolute legal provisions'.

3 In contrast, the principle was even found in the original Article 77 of the Entwurfe eines Bürgerlichen Gesetzbuches für das Deutsche Reich (ie Draft of a Civil Code for the German Reich) (1888): 'In order to conclude a contract, it is necessary for the contracting parties to declare their corresponding intentions to each other'; This Article 77 was then deleted by the second commission, see Commission's Report, 156, in B. Mugdan, Die gesammten Materialien des Bürgerlichen Gesetzbuchs für das Deutsche Reich, volume I (1899) 688. 
ples as simply being obviously valid. ${ }^{4}$ In contrast to German law, other states have codified numerous principles. ${ }^{5}$

However, there are also explicitly listed legal principles in German law. The Basic Law contains the most well-known ones: fundamental rights are principles par excellence. At the European level, it is particularly important to mention the fundamental freedoms set out in the TFEU and the DCFR. The mere fact that legal principles dominate our highest-ranking codifications shows their enormous importance in reaching legally sound decisions, and thus forces legal scholars to discuss them.

This article deals with the question of whether and how legal principles can be applied in German private law to resolve questions of law. The purpose of legal methodology is to clarify how legal principles affect the resolution of a case and how they can be harnessed for this purpose. The main area of application of methodological work with legal principles is for instances where the law does not contain an answer, or at least does not contain a clear answer, to a legal problem. If there is a gap, a court has to decide such unresolved issues in the last resort. The judge is obligated to make a decision. ${ }^{6}$ Moreover, s/he cannot simply decide, but rather needs to be able to justify the decision rationally with good arguments. ${ }^{7}$ For this purpose, as part of an extensive methodological arsenal, the judge can utilise the appraisals of existing law, and develop a solution therefrom. In

4 Thus W. Flume, 'Rechtsgeschäft und Privatautonomie', in Festschrift 100 Jahre Deutscher Juristentag, volume I (Karlsruhe: Müller, 1960) 135, 136 et seq; W. Flume, Allgemeiner Teil des Bürgerlichen Rechts, Das Rechtsgeschäft, volume 2 (Berlin: Springer, 1965) sec 1.1, 1; agreeing C.-W. Canaris, 'Wandlungen des Schuldvertragrechts - Tendenzen zu einer «Materialisierung»' Archiv für die civilistische Praxis 200 (2000) 273, 277; R. Bork, Allgemeiner Teil des Bürgerlichen Gesetzbuchs ( $4^{\text {th }}$ ed, Tübingen: Mohr Siebeck, 2016) para 99.

5 For pacta sunt servanda see for instance fn 75; for the violation of moral principles see fn 69 .

6 L. Enneccerus and H.C. Nipperdey, Lehrbuch des Bürgerlichen Rechts $\left(15^{\text {th }}\right.$ ed, Tübingen: Mohr Siebeck, 1960) 336; A. Meier-Hayoz, 'Strategische und taktische Aspekte der Fortbildung des Rechts', JuristenZeitung 1981, 417; B. Rüthers, Ch. Fischer and A. Birk, Rechtstheorie mit juristischer Methodenlehre ( $8^{\text {th }}$ ed, Munich: C H Beck, 2015) para 314; see also K. Larenz, Methodenlehre der Rechtswissenschaft ( $6^{\text {th }}$ ed, Berlin: Springer, 1991) 368, 402; Historically on the so-called prohibition on denying justice see E. Schumann, 'Das Rechtsverweigerungsverbot' Zeitschrift für Zivilprozess 81 (1968) 79, 83 et seq; M.Th. Fögen, 'Schrittmacher des Rechts: Anmerkungen zum Justiz- und Rechtsverweigerungsverbot', in Festschrift Kramer (Basel et al: Helbing \& Lichtenhahn, 2004) 3 et seq.

7 On the obligation to give reasons, German Federal Constitutional Court (BVerfG), decision of 19 May 1992, 1 BvR 986/91, BVerfGE 86, 133, 144 et seq; see from the ordinary law, sec 30(1) German Federal Constitutional Court Act (BVerfGG); sec 313(1) no 6(3) Code of Civil Procedure (ZPO); sec 267(1), 275 Code of Criminal Procedure (StPO) or sec 117(2) no 5 Rules of the Administrative Courts (VwGO); sec 60(2), 4, 96(2) Labour Courts Act (ArbGG). 
particular, in addition to the option to interpret existing laws, jurisprudence also has the power to develop the law. ${ }^{8}$ Judges must therefore inevitably pose the question of how to resolve a legal problem in the spirit of the existing law if there is no written rule. S/he therefore has to explore existing appraisals of the law and harness them to resolve the specific legal problem.

A line of argument based on principles therefore gains its power of persuasion solely therefrom. ${ }^{9}$ Principles represent stability in law, legal certainty, and transparency. Principles also seem difficult to rebut; they have a superordinate character compared with individual specific legal provisions. It is difficult to oppose them, unless one can claim that the circumstances are sufficient for there to be an exception to the principle. However, one who claims such special circumstances bears the burden of argumentation.

In addition to these advantages of reasoning with legal principles, however, there is also a risk that the mere reference to a principle replaces the deeper analysis of the specific case and its circumstances, and thus the justice of the individual case is left out of consideration. Decisive aspects of the individual case, which could force a decision that deviates from the principle, are in danger of being overlooked. Furthermore, the fact that legal principles are often uncodified can lead to a temptation to 'invent' new legal principles without sufficient connection to the existing law. Moreover, without precise determination of their scope, particularly for unregulated legal problems, it opens the door to decisions lacking transparent justification, that is, ultimately, arbitrariness.

It is therefore necessary to identify legal principles from a methodological point of view, and to clarify the question as to whether and how they can be applied to resolve the specific case without constitutional objections. First, a conceptual and characterising delimitation and narrowing is required (II). Then, the prerequisites for developing and forming legal principles must be clarified (III). The focus then turns to the application of legal principles as a methodological construction in the specific individual case (IV). Eventually, a methodological consideration of legal principles at the European level is required (V).

8 Explicitly BVerfG, decision of 14 February 1973, 1 BvR 112/65, BVerfGE 34, 269, 286 et seqSoraya; BVerfG, decision of 8 April 1987, 2 BvR 687/85, BVerfGE 75, 223, 243 et seq - Kloppenburg. 9 Similar Y. Adar and P. Sirena, 'Principles and Rules in the Emerging European Contract Law: From the PECL to the CESL, and Beyond' 9 European Review of Contract Law 1, 8 et seq (2013). 


\section{What characterises a Legal Principle?}

\section{The Concept of the Legal Principle}

A definition of the 'general legal principle' (synonymously 'principle') must include various components. In the same way that legal doctrine is more than the law, ${ }^{10}$ so are legal principles more than the legal norms of the laws. Legal principles develop from the totality of the written and unwritten legal norms.

The term 'legal principle' or the synonymous term 'general legal principle' is rarely clarified. Larenz described principles as guiding criteria of legal standardisation, which are able to justify decisions on the basis of their own persuasiveness. ${ }^{11}$ However, this description is fairly vague, and does not allow any distinction from the legal concept and the legal rule. In Germany, Esser fundamentally advanced the distinction between norms (Rechtssätze) and principles. He characterised principles as pre-positive law that influences the interpretation of norms and therefore is transformed to a more concrete level. ${ }^{12}$ Dworkin established the almost generally accepted distinction between rules and principles. ${ }^{13}$ He identified principles as norms which - without being rules - can serve as arguments for individual rights. ${ }^{14}$ Building on Dworkin and Esser, scholars refined and modified the doctrine of principles in detail. ${ }^{15}$ However, they all share the opinion that rules are either met or not, and thus prescribe a decision. ${ }^{16}$ Principles, by contrast,

10 Here A. Voßkuhle, in W. Hoffmann-Riem, E. Schmidt-Aßmann and A. Voßkuhle, Grundlagen des Verwaltungsrechts, volume 1 ( $2^{\text {nd }}$ ed, Munich: C H Beck, 2012) sec 1 para 6; see the various conceptualisations for Ch. Waldhoff, in G. Kirchhof, S. Magen and K. Schneider, Was weiß Dogmatik? (Tübingen: Mohr Siebeck, 2012) 17, 22 et seq; Ch. Möllers, in Hoffmann-Riem, SchmidtAßmann and Voßkuhle, this note above, sec 3 para 35 et seq.

11 Larenz, $\mathrm{n} 6$ above, 421.

12 J. Esser, Grundsatz und Norm in der richterlichen Fortbildung des Privatrechts (Tübingen: Mohr, 1956) 94.

13 R. Dworkin, Taking Rights Seriously (Cambridge/Mass: Harvard University Press, 1978) 23 et seq.

14 Dworkin, $\mathrm{n} 13$ above, 90.

15 Eg C.W. Canaris, Systemdenken und Systembegriff in der Jurisprudenz ( $2^{\text {nd }}$ ed, Berlin: Duncker \& Humblot, 1983) 52 et seq; R. Alexy, 'Rechtsregeln und Rechtprinzipien' Archiv für Rechts- und Sozialphilosophie Beiheft 25 (1985) 13, 15 et seq; Adar and Sirena, n 9 above, 13 et seq, who hold for the legitimizing function of principles to be the most important characteristic of principles.

16 Dworkin, $n 13$ above, 24 et seq; R. Alexy, Theorie der Grundrechte (Frankfurt/Main: Suhrkamp, 1986) 76 (english: Theory of Constitutional Rights, Oxford: Oxford University Press, 2002); Alexy, n 15 above, 20. 
cannot absolutely specify a decision because they must be balanced with other principles. ${ }^{17}$ To resolve a problem, principles can only be useful after concretisation. ${ }^{18}$ They also require substantiation, because they are not yet classifiable as such. ${ }^{19}$ In this respect, principles are (only) optimisation requirements which can be fulfilled to various degrees and be incorporated into the decision. ${ }^{20}$ As optimisation requirements they do not permit any resolution of the decision but rather support decision-making. ${ }^{21}$ Large parts of the literature, however, are critical of the absoluteness of this theory's claim to differentiate rules from principles. ${ }^{22}$ The distinction between principles and rules cannot be derived from the Basic Law. ${ }^{23}$ It is also unclear when a norm is a principle and when it is a rule. ${ }^{24}$ The distinction between principles and rules is often a gradual one. ${ }^{25}$

After all, a definition of a legal principle must contain at least three components: ${ }^{26}$

(1.) Legal principles or (often used synonymously) principles of law are initially only partly standardised and often not set out in law at all. They are extracted from the legal system as the totality of the written and unwritten legal norms and are more than legal concepts.

17 Dworkin, $\mathrm{n} 13$ above, 26.

18 Canaris, $\mathrm{n} 15$ above, 57.

19 E. A. Kramer, Juristische Methodenlehre ( $5^{\text {th }}$ ed, Munich: C H Beck, 2016) 275 et seq.

20 Alexy, n 15 above, 19; Alexy, n 16 above, 75 et seq; R. Alexy, 'Rechtssystem und Praktische Vernunft' Rechtstheorie 18 (1987) 405, 407, agreeing Larenz, n 6 above, 475; N. Jansen, Die Struktur der Gerechtigkeit (Baden-Baden: Nomos, 1998) 106 et seq; A. Röthel, Normkonkretisierung (Tübingen: Mohr Siebeck, 2004) 146 et seq, 225 et seq.

21 Vividly D. Merten, Handbuch der Grundrechte, volume III (Heidelberg: Müller, 2009) sec 68 para 25; as above Alexy, n 15 above, 15 et seq; Larenz, n 6 above, 474.

22 U. di Fabio, Das Recht offener Staaten (Tübingen: Mohr Siebeck, 1998) 69; J.F. Lindner, Theorie der Grundrechtsdogmatik (Tübingen: Mohr Siebeck, 2005) 54: '(...) the norm theory approach has not established itself'; J.H. Klement, 'Vom Nutzen einer Theorie, die alles erkärt' JuristenZeitung 2008, 756 et seq; J.H. Klement, 'Schlusswort', JuristenZeitung 2009, 560 et seq and the authors in the following footnotes.

23 Lindner, $\mathrm{n} 22$ above, 54.

24 M. Sachs, in K. Stern, Das Staatsrecht der Bundesrepublik Deutschland, volume III/1 (Munich: C H Beck, 1988) 502; M. Jestaedt, Grundrechtsentfaltung im Gesetz (Tübingen: Mohr Siebeck, 1999) 214; M. Jestaedt, 'Die Abwägungslehre: ihre Stärken und ihre Schwächen', in Festschrift Isensee (Heidelberg: Müller, 2007) 253, 261; Klement (2008), n 22 above, 760.

25 M. Auer, Materialisierung, Flexibilisierung, Richterfreiheit (Tübingen: Mohr Siebeck, 2005) 48, 135.

26 Adar and Sirena, $\mathrm{n} 9$ above, 8 et seq name six components. 
(2.) They allow a certain generalisation. ${ }^{27}$ Principles form 'the deep structure of the law'. ${ }^{28}$ They generally claim normative validity and lead to a presumption of conformity. ${ }^{29}$

(3.) However, principles are frequently not classifiable and require further specification through legal rules or balancing. Or in the words of Bydlinski: 'They are thus guiding principles and grounds of justification of a legal provision, but not the positive provision itself. ${ }^{30}$ Canaris illustrates: 'Principles unfold their true meaning foremost by interacting in mutual addition and restriction.'

\section{Differentiation from Legal Concepts and Legal Doctrine}

Legal concepts have a higher status than legal principles. They provide reasons for norms which formulate the requirements or prohibitions. ${ }^{31}$ Such legal concepts, which are to some extent also referred to as values, ${ }^{32}$ are of a higher level of abstraction, and frequently too general to be used to resolve a case. Legal concepts, such as justice, expediency, and legal certainty, must therefore also be further specified to make it possible to have transparent, persuasive trains of thought and justification. Otherwise there is a risk that the concept is only used as an empty phrase. ${ }^{33}$

Legal principles require further specification to be applicable for the specific case. A legal rule can exist in a legal doctrine developed by jurisprudence, such as the obligation to contract. A legal doctrine in its application is then eventually a rule in the sense of Alexy or a positive rule in the sense of Bydlinski. In the

27 J. Basedow, 'Das BGB im künftigen europäischen Privatrecht: Der hybride Kodex’ Archiv für die civilistische Praxis 200 (2000) 446, 453. In detail, also C.-W. Canaris, Die Feststellung von Lücken im Gesetz ( $2^{\text {nd }}$ ed, Berlin: Duncker \& Humblot, 1983) 47 et seq.

28 K.F. Röhl and H.Ch. Röhl, Allgemeine Rechtslehre ( ${ }^{\text {rd }}$ ed, Cologne: Heymanns, 2008) 283.

29 Röhl and Röhl, n 28 above, 284.

30 F. Bydlinski, Juristische Methodenlehre und Rechtsbegriff ( $2^{\text {nd }}$ ed, Vienna et al: Springer, 1991) 132.

31 M. Mahlmann, Rechtsphilosophie und Rechtstheorie ( $3^{\text {rd }}$ ed, Baden-Baden: Nomos, 2015) sec 24 para 13.

32 W. Fikentscher, Methoden des Rechts, volume IV (Tübingen: Mohr, 1977) 394 et seq.

33 This particularly applies for the concept of the 'nature of the matter'. See H. Dernburg, Pandekten, volume 1 ( $7^{\text {th }}$ ed, 1902) 84; H. Dernburg, System des römischen Rechts, volume 1 ( $8^{\text {th }}$ ed, 1911) sec 32.2, 64; A. von Thur, Allgemeiner Teil des Bürgerliches Rechts, volume 1 (1910) 42; A. Kaufmann, Analogie und "Natur der Sache" ( ${ }^{\text {nd }}$ ed, Heidelberg: von Decker, 1982); F. Müller, Normstruktur und Normativität (Berlin: Duncker \& Humblot, 1966) 94 et seq; Larenz, n 6 above, 417 et seq with citations; Canaris, n 27 above, 100. 
interim it is substantiated and has also acquired a binding character through the development of tangible, directly classifiable features. Thus, for example, liability for apparent rights is established as a legal principle from Sections 171, 172 BGB and Section 405 BGB. This principle is then developed into the legal doctrine of agency by estoppel ${ }^{34}$ and apparent authority. ${ }^{35}$

\section{The Derivation and Substantiation of Legal Principles}

\section{The Derivation of unwritten Legal Principles}

If a principle is codified, the question of its derivation is unnecessary. Here, the only question is when a law can be 'elevated' into a legal principle, and thus has a ripple effect on other provisions, must be taken into consideration for their interpretation, or can serve as the basis for further development of the law in the area of law concerned. First, there is the possibility that the law itself ascribes to a legal rule the status of a legal principle. Article 5(1) Sentence 1(3) TEU, for example, explicitly speaks of the principle of conferral and of the principle of subsidiarity. In German law, on the other hand, one rarely finds such clear statements. ${ }^{36}$

\section{a) Historical Derivation}

It is more difficult to derive legal principles which are not explicitly stated. In large parts of the ordinary law this is actually the case. In part, legal principles are explained from a historical perspective. ${ }^{37}$ There is no doubt that numerous

34 Federal Supreme Court (BGH), Judgment of 15 October 1987, III ZR 235/86, BGHZ 102, 60, 64; then without the doctrinal derivation: BGH, Judgment of 11 May 2011, VIII ZR 289/09, BGHZ 189, 346 para 15 - use of a third-party eBay member's account.

35 BGH, Judgment of 20 January 1983, VII ZR 32/82, BGHZ 86, 273, 274 et seq - apparent authority.

36 For example, critical of the 'General Principles' set out in section 3 German Securities Acquisition and Takeover Act (WpÜG), P. Versteegen, in Kölner Kommentar zum Wp ÜG ( $2^{\text {nd }}$ ed, Cologne: Heymanns, 2010) sec 3 para 2: Declared aims, use of which is questionable; U. Noack and T. Holzborn, in E. Schwark and D. Zimmer, Kapitalmarktrechtskommentar $\left(4^{\text {th }}\right.$ ed, Munich: C H Beck, 2010) sec 3 para 1.

37 See the examples in J. Esser, Grundsatz und Norm ( $4^{\text {th }}$ ed, Tübingen: Mohr, 1990) 317 et seq; J. Rückert, in Historisch-kritischer Kommentar zum BGB (HKK-BGB) (Tübingen: Mohr Siebeck, 
legal principles come from centuries of tradition, in some cases even millennia. ${ }^{38}$ Legal constructions such as the prohibition in laesio enormis or clausula rebus sic stantibus can only provide initial approaches to justify the current principles of law or legal rules. On closer inspection, however, one will find that many legal principles have developed over the centuries. Because the conditions change the comparison with historical examples is not always convincing. ${ }^{39}$ Ultimately, the necessary flexibility would not be achieved by forming new principles if these were derived exclusively from the past. ${ }^{40}$ Legal doctrine, correctly understood, does not remain in the jurisprudence of concepts, but rather changes with the requirements of the legislation and the case law. ${ }^{41}$

2003) with sec 1 para 80 et seq; and R. Zimmermann, Law of Obligations (Cape Town: Juta, 1992); R. Zimmermann, 'Das römisch-kanonische ius commune als Grundlage europäischer Rechtseinheit' JuristenZeitung 1992, 8 et seq; R. Zimmermann, 'Heard melodies are sweet, but those unheard are sweeter...' Archiv für die civilistische Praxis 193 (1993) 121 et seq, who calls for a European ius commune.

38 See, for example Aristotle, Nicomachean Ethics, $5^{\text {th }}$ Book, 4-9 (Justice and Fairness); art 104 et seq Constitutio Criminalis Carolina (CCC) of 27 July 1532 (Principle of Legality); Ch. von Wolff, Grundsätze des Natur- und Völkerrechts (1754) sec 438: 'When two or more jointly agree on one or more promises, it is a contract (pactum or pactio).' (pacta sunt servanda); Ulp D 1.1.10.1.: 'Juris praecepta sunt haec: honeste vivere, alterum non laedere, suum cuique tribuere' (alterum non laedere).

39 See only the various groups of cases of frustration of contract which have developed in the course of time in the case law. For example, the overview in Ch. Grüneberg, in Palandt BGB ( $77^{\text {th }}$ ed, Munich: C H Beck, 2018) sec 313 para 25 et seq.

40 Critical against Zimmermann (1992, Law of Obligation), n 37 above, for example, D. Simon, 'Zwillingsschwestern und Stammesbrüder oder What is What?' Rechtshistorisches Journal 11 (1992) 574, 577 et seq; W. Wiegand, 'Back to the future?' Rechtshistorisches Journal 12 (1993) 277 et seq; F. Kübler, 'Traumpfade oder Holzwege nach Europa?' Rechtshistorisches Journal 12 (1993) 307, 310 et seq.

41 Thus R. von Jhering, Geist des römischen Rechts, volume 1 ( $4^{\text {th }}$ ed, 1878) 14: 'Through Roman law, but beyond it'; here W. Fikentscher, Methoden des Rechts, volume II (Tübingen: Mohr, 1976) 165. On the necessary flexibility, see W. Brohm, Veröffentlichungen der Vereinigung der Deutschen Staatsrechtslehrer (VVDStRL) 30 (1972) 245, 249; U. Volkmann, JuristenZeitung 2005, 261, 262 et seq. 


\section{b) Induction: the systematic and evaluative Comparison of the Development of new General Legal Principles}

It therefore seems more convincing to derive principles directly from the value judgements of the law. Literature also favours induction to derive legal principles, namely, reasoning from the specific to the general. ${ }^{42}$

The systematic derivation of a general legal principle can happen in at least three ways: Firstly, the principle is sometimes found in a provision which is too restrictive. It can then be extended beyond the original application of the norm to other cases. It is generally accepted that the provision in Section 254 BGB on contributory negligence in the law on damages is considered a legal principle, and the concept of contributory negligence is understood in non-technical terms. Those who disregard the necessary duty of care when one of their legal interests is harmed breach an obligation, along with the actual injuring party. They are then accused of 'culpability to themselves', so that it would be unconscionable to claim full compensation. ${ }^{43}$ The provision also applies for strict liability ${ }^{44}$ which does not require any fault at all. Moreover, the provision in Section 254 BGB is even referred to outside of the law on damages, eg for the claim for compensation under neighbourhood law in Section 906(2) Sentence 2 BGB $^{45}$ or for the claim for disposal in Section 1004 BGB. ${ }^{46}$ The principle also applies in public law. ${ }^{47}$

Secondly, the principle can be extracted from a single provision. ${ }^{48}$ This applies, for example, to the principle of good faith in Section 242 BGB. ${ }^{49}$ Fundamental rights are referred to as legal principles and also arise from a single legal provision.

42 In detail on this, see Aristotle, Aristotle's Prior Analytics, or Lehre vom Schluss (Edition Kirchmann, 1877) $23^{\text {rd }}$ ch 142; Bacon, Novum Organum, Book I (1620) aphorismus CIV, 82.

43 BGH, Judgment of 18 April 1997, V ZR 28/96, BGHZ 135, 235, 240 - roots in the tennis court.

44 BGH, Judgment of 23 June 1952, III 297/51, BGHZ 6, 319, 320 - obligation to pay compensation between motorists; BGH, Judgment of 13 April 1956, VI 347/54, BGHZ 20, 259, 263 et seqoperational risk.

45 BGH, Judgment of 18 September 1987, V ZR 219/85, NJW-RR 1988, 136, 138.

46 BGH, Judgment of 18 April 1997, V ZR 28/96, BGHZ 135, 235, 239 et seq - roots in the tennis court.

47 BGH, Judgment of 29 March 1971, III ZR 98/69, BGHZ 56, 57, 63: 'the legal rationale contained in Section 254 BGB.'.

48 See A. Meier-Hayoz, Berner Kommentar zum schweizerischen Privatrecht, introduction to Art. 1-10 Swiss Civil Code (ZGB) (Bern: Stämpfli, 1962) art 1 para 406: 'One often refers to a legal norm of broader scope as a general principle of law.'.

49 J. Neuner and E. Wolf, Allgemeiner Teil des Bürgerlichen Rechts (11 ${ }^{\text {th }}$ ed, Munich: C H Beck, 2016) sec 4 para 49. 
In contrast to other codifications of modern times, however, the BGB mostly forgoes mentioning principles and doctrines, but rather assumes them. Principles such as freedom of contract, pacta sunt servanda, the principle of abstraction, or constructs of reasoning, such as the right to develop the law, were not incorporated into the $\mathrm{BGB}$ or the GG by the German legislator, but were rather assumed. ${ }^{50}$ As one of the few principles, the concept of property as a right to deal with the item at will, has been included in Section 903 Sentence 1 BGB. ${ }^{51}$ Thus, thirdly, it is possible to establish legal principles by induction, the reasoning from the specific to the general..$^{52}$ Thus, one can find principles which are only indirectly inferred from the law. This is called induction. This derivation is among the most difficult circumstances in which to determine the legal position. Therefore, principles such as pacta sunt servanda must be further substantiated (see right below).

\section{Substantiation of Legal Principles as a necessary second Step}

However, before principles can be classified, they must be further substantiated. The primacy of rules over principles is emphasised. ${ }^{53}$ This correct legal rationale warrants further discussion. Because legal concepts are abstract, these are pretexts and empty phrases without further specification, and are therefore seldom good for direct classification. Similarly, it may be stated that legal principles also cannot be used directly as justification as they are too uncertain and thus are yet unclassifiable. ${ }^{54}$ Additional interim steps are thus required before utilising legal principles to resolve cases. The aim is to find a rule which is directly classifiable. The processes of (a) deduction, and (b) balancing serve this purpose.

50 In contrary, other legal system have codified legal principles to a greater extent, see fn 69 and fn 75; concerning the development of the law see art 1 schweizerisches ZGB; art 12 para 2 codice civile, art 4 no 1 Código Civil.

51 A proposal to delete this doctrine was rejected, see Commission's Report, 4, in B. Mugdan, Die gesammten Materialien des Bürgerlichen Gesetzbuchs für das Deutsche Reich, volume III (1899) 997. In any event, the definition of property was already in the Codex Maximilianeus Bavaricus Civilis (1759) $2^{\text {nd }} \mathrm{ch} 2^{\text {nd }}$ part sec 1 . On the concept of property in detail, M. Auer, Der privatrechtliche Diskurs der Moderne (Tübingen: Mohr Siebeck, 2014).

52 In detail on this, see Aristotle, n 42 above; Bacon, n 42 above. See also Canaris, n 27 above, 97. 53 Neuner, n 49 above, sec 4 para 51.

54 M. Jestaedt, Das mag in der Theorie richtig sein... (Tübingen: Mohr Siebeck, 2005) 59 et seq calls for a strict separation between discovering law and producing law; Kramer, n 19 above, 276 calls for honesty in the methodology for deriving general legal principles. 


\section{a) Substantiation of Legal Principles into Legal Rules or Legal Doctrine}

In a second step, it is necessary to specify the general legal principle. This deduction, that is, reasoning from the general to the specific, can lead to a new legal rule. Ideally, it develops its own legal doctrine with similar factual conditions. Such a new legal doctrine can be developed by development of the law from the legal principle. Here, the substantiation is vertical, from the level of the legal principle to the level of the legal doctrine. Whereas the legal rule, in case of doubt, only represents an entitlement, the legal doctrine goes beyond this because it often connects several ideas. ${ }^{55}$ This is immediately clarified with the examples of the obligation to contract, price control, and frustration of contract. The case law specifies the legal doctrines newly developed in this way with groups of cases and similar factual conditions. They are more than judge-made law and therefore cannot be abolished by case law.

\section{b) Substantiation through Balancing}

The necessary specification of principles can also happen via balancing. For example, the case law developed numerous interim steps to substantiate the review of fundamental rights. Fundamental rights are principles. ${ }^{56}$ The case law developed numerous interim steps to refine the review of fundamental rights. It is often a matter of the practical concordance for contrary fundamental rights and thus conflicting principles. In this case, the substantiation is horizontal because principles on the same level are balanced with one another.

\section{Legal Principles in Private Law: Derivation and Substantiation of Private Autonomy}

In private law, the legal text is frequently more specific than in constitutional law; the need for legal principles is less intense. However, there are also principles which must be further substantiated by sub-principles and individual value judgements. ${ }^{57}$ In public law, the principles are then substantiated into interim

55 Thus private autonomy includes self-determination, personal responsibility, and the protection of legitimate expectations, see Canaris, $\mathrm{n} 15$ above, 50 et seq.

56 Alexy, $\mathrm{n} 16$ above, 104.

57 Canaris, $\mathrm{n} 15$ above, 57 et seq. 
stages (Zwischenschritte), review stages (Prüfungsschritte), guiding principles (Leitbilder). Private autonomy is referred to as an essential basic structure of contract law. ${ }^{58}$ A subtle interplay ${ }^{59}$ of the principle of intention, principle of trust, and contractual justice as equivalence of benefit and consideration ${ }^{60}$ and the principle of a binding contract (pacta sunt servanda) are referred to as legal principles of contract law. Freedom of contract is the manifestation of private autonomy.

\section{Inductive Derivation of pacta sunt servanda}

\section{a) Freedom of Contract as a Consequence of Freedom of Will}

Private autonomy includes freedom of contract, but also freedom of ownership (Section 903 BGB), freedom to marry (Section 1297 BGB) and testamentary freedom, thus the right to freely dispose of one's assets in the event of death (Section 1937 BGB). ${ }^{61}$ Freedom of contract in turn includes freedom to conclude contracts, freedom to choose a contractual partner, freedom of content, and generally freedom of form, but also freedom to amend and cancel. ${ }^{62}$ The concept of freedom of contract was first introduced in the mid-19 ${ }^{\text {th }}$ century. ${ }^{63}$ Freedom of contract is based on the intentions of the parties. ${ }^{64}$ The parties can determine their legal relationships between themselves at their discretion, insofar as there are no conflicting legal provisions.

$58 \mathrm{~J}$. Ellenberger, in Palandt BGB, n 39 above, introduction to sec 145 para 4 a et seq.

59 Thus the formulation of Kramer, $\mathrm{n} 19$ above, 104.

60 On the corrective justice of Aristotle see Th. Möllers, Juristische Methodenlehre (Munich: C H Beck, 2017) sec 1 para 98.

61 Motive, $\mathrm{n} 2$ above, 2.

62 Bork, n 4 above, para 661; Neuner, n 49 above, sec 10 para 33 et seq; Th. Möllers, 'Themenklausur - Bürgerliches Recht: Der Verbraucherschutz im Zivilrecht' Juristische Schulung 1999, 1191, 1192.

63 F.C. von Savigny, Das Recht des Obligationenrechts, volume 2 (1853) sec 72-78; B. Windscheid, Lehrbuch des Pandektenrechts, volume II ( $8^{\text {th }}$ ed, 1900) sec 312 fn 5 with further citations; see W. Scherrer, Die geschichtliche Entwicklung des Prinzips der Vertragsfreiheit (Basel: Helbing \& Lichtenhahn, 1948) 33 et seq; J. Rückert, in D. Klippel, Naturrecht im 19. Jahrhundert (Goldbach: Keip, 1997) 135, 145 et seq.

64 Motive, $\mathrm{n} 2$ above, 126: 'Legal transaction in the sense of the Draft is a personal declaration of intent, aimed at emphasising a legal outcome, which occurs under the legal system as a result, because it is intended.'. 
The parties are generally responsible for agreeing the essentialia negotii, the essential components of the contract, such as for example, the purchase object and the purchase price. The price is not controlled. The parties may also conclude unreasonable contracts. ${ }^{65}$ That corresponds with the liberal approach of Adam Smith who described the market as the 'invisible hand' where demand and supply regulate themselves. ${ }^{66}$ The underlying idea is that the conflict of interests between the parties leads to a correct result through the contract; one refers to the 'guaranteed correctness' of the negotiation. ${ }^{67}$ Hobbes accurately stressed that it is the parties who are best able to determine the value of the item. ${ }^{68}$ This concept has been taken up by the BGB. Thus, for example, usury according to Section 138(2) $\mathrm{BGB}$ requires in addition to the conspicuous disparity between benefit and consideration, that freedom of choice is impaired, such as with the exploitation of plight. This corresponds with the legal position in numerous other legal systems. ${ }^{69}$ Thus, only procedural fairness was to be ensured, guaranteed process, by protection against mistake or fraud (Sections 119,123 et seq, 142 et seq BGB). ${ }^{70}$

\section{b) The Justification of a binding Contract (pacta sunt servanda)}

The counterpart to freedom of contract is the binding contract or contractual fidelity (pacta sunt servanda). The principle of a binding contract is not of Roman origin, ${ }^{71}$ but rather was first developed for all types of contract by canon law, the

65 Higher Regional Court (OLG) of Cologne, Judgment of 8 December 2006, 19 U 109/06, Multimedia und Recht 2007, 446, 448: Purchase of a sugar beet harvester worth 60,000 euros in an eBay auction for 51 euros; agreeing, M.-P. Weller, Die Vertragstreue (Tübingen: Mohr Siebeck, 2009) 170. 66 A. Smith, Wealth of Nations ( $9^{\text {th }}$ ed, 1799) volume III, book IV, ch II, Of Restraints upon the Importation from foreign Countries of such Goods as can be produced at Home, 181.

67 W. Schmidt-Rimpler, 'Grundfragen einer Erneuerung des Vertragsrechts' Archiv für die civilistische Praxis 147 (1941) 130, 149 et seq; W. Schmidt-Rimpler, 'Zum Vertragsproblem', in Festschrift Raiser (Tübingen: Mohr, 1974) 3, 5 et seq; M. Lieb, 'Sonderprivatrecht für Ungleichgewichtslagen? Überlegungen zum Anwendungsbereich der sogenannten Inhaltskontrolle privatrechtlicher Verträge' Archiv für die civilistische Praxis 178 (1978) 196, 206.

68 Vividly, Th. Hobbes, Leviathan ( $2^{\text {nd }}$ ed, 1886) part I, ch 15, 74: 'The value of all things contracted for, is measured by the appetite of the contractors: and therefore the just value is that which they be contented to give.'.

69 Art 21 OR (Swiss Code of Obligations); art 282 port cc (Portuguese código civil); art 388 Polish Civil Code of 23 April 1964.

70 On this procedural concept of fairness, see K. Zweigert and H. Kötz, Einführung in die Rechtsvergleichung ( $3^{\text {rd }}$ ed, Tübingen: Mohr, 1996) 320 et seq.

71 Roman law did not have any general option to be able to sue for contractual obligations. See in detail, G. Kegel, Vertrag und Delikt (Cologne: Heymanns, 2002) 3 et seq. 
late scholasticism, and the natural $\operatorname{law}^{72}$ and German sources of law. ${ }^{73}$ The principle is clearly mentioned in the Draft of the $\mathrm{BGB},{ }^{74}$ but not in the BGB because the Second Commission assumed that the rule that the concurrence of wills is contractually binding is well known. Therefore, the Second Commission deleted it from the Draft. ${ }^{75}$

As the principle of a binding contract cannot be taken directly from the law one must derive it indirectly from the law by induction. Thus a person who offers to conclude a contract with another person is 'bound by the offer', Section 145 BGB. The contract and the contractual obligation follow from the deliberate statement to accept an offer. Without consensus, this leads to disagreement under Sections 154 et seq BGB. The mistake - the conflict of intention and declaration is initially irrelevant for the binding effect. The contract is valid despite the mistake and only permits a challenge under Sections 119, 142 BGB. ${ }^{76}$ The binding contract can be discerned from the synallagmatic fulfilment obligations of the individual types of contract ${ }^{77}$ or the general fulfilment obligations on the time of performance (Section $271 \mathrm{BGB}$ ), the right of retention (Section $273 \mathrm{BGB}$ ), and impossibility (Section 275 BGB). Moreover, good faith (Section 242 BGB) is able to justify the obligation for contractual fidelity. ${ }^{78}$ Moreover, under the 2001 reform of the law of obligations, freedom of contract and the binding contract can be established by Sections 241, 311(1) BGB. ${ }^{79}$ The binding contract can be derived from the provisions cited by induction.

72 See Wolff, $\mathrm{n} 38$ above, sec 438: 'When two or more jointly agree on one or more promises, it is a contract (pactum or pactio).' See K.-P. Nanz, Die Entstehung des allgemeinen Vertragsbegriffs im 16.-18. Jahrhundert (Munich: Schweitzer, 1985) 149 et seq; H. Coing, Europäisches Privatrecht, volume 1 (Munich: C H Beck, 1985) 397 et seq; in detail, Kegel, $\mathrm{n} 71$ above, 3 et seq.

73 Sachsenspiegel, Leipziger Ausgabe (1595) $1^{\text {st }}$ book, $7^{\text {th }}$ art: 'That which a man promises, so should he keep'; Ch.F. von Glück, Ausführliche Erläuterung der Pandekten nach Hellfeld - ein Kommentar für meine Zuhörer, volume IV (1786) 279 et seq with reference to the German legal rule: 'A man's word is his bond.' See also F.C. von Savigny, System des heutigen Römischen Rechts (1840) volume III, 309.

74 Sec 77 Entwurf eines Bürgerliches Gesetzbuches für das Deutsche Reich (1888), n 3 above.

75 Commission's Report, n 3 above. Otherwise the clear rule in art 19 Swiss OR, art 353 Polish Civil Code, art 1134, 1 cc.

76 S. Hofer, in $H K K-B G B$, n 37 above, with sec 145 para 10.

77 Such as from the contract of sale (sec 433), rental agreement (sec 535), contract for work (sec 633) or contract for services (sec 631 BGB).

78 BGH, Judgment of 17 December 1982, V ZR 306/81, BGHZ 86, 167, 171 - increase in a ground rent in the absence of a contractual adjustment clause.

79 A. Thier, in Historisch-kritischer Kommentar zum BGB (HKK-BGB) (Tübingen: Mohr Siebeck, 2007) sec 311 I para 1; Weller, $n 65$ above, 170. 


\section{Freedom of Contract and supposedly contradictory Legal Doctrines}

These examples shall clarify the vagueness of describing certain legal institutes with a precise legal principle.

\section{a) The disputed Justification of the Obligation to Contract in Legal Doctrine}

aa) The freedom of contract as freedom to conclude contracts also generally means that everyone may personally choose his or her contractual partners. Nevertheless, it is accepted that there must be circumstances in which a contract must be concluded against the will of one contracting party. What if the only chemist for miles around is not willing to sell vital medicine to a patient? ${ }^{80}$ Or must the theatre critic be permitted to visit the theatre, even if there is reason to fear that $s /$ he will report negatively on the performance ${ }^{81}$ In some cases, the legislator has set out special legal rules, such as against those with a monopoly position. ${ }^{82}$ Further rules arise in anti-trust law for market abuse and the nondiscrimination principle in competition law. ${ }^{83}$ Moreover, the requirements for such a claim to conclusion of a contract have been discussed. Such an obligation to contract must be affirmed when there are no reasonable alternatives, the customer is dependent on the service, or the refusal is not objectively justified.

$\mathrm{bb}$ ) There is a lot of dispute regarding legal doctrine and legal methodology. The case law had originally established the obligation to contract with Section 826 BGB because in some cases it was immoral to refuse to conclude a contract. ${ }^{84}$ That is unconvincing because a claim to conclude a contract must be

80 Bork, n 4 above, para 666.

81 The Reichsgericht (Imperial Court of Justice, RG) rejected the obligation to contract, Judgment of 7 Nobember 1931, V 106/31; RGZ 133, 388, 392 - theatre critic.

82 Sec 48 et seq German Federal Lawyer's Act (BRAO) of 1 August 1959, BGBl I, 565, sec 1, 5(2) German Compulsory Insurance Act (PflVG), sec 21(2) German Air Traffic Act (LuftVG), sec 22 German Carriage of Persons Act (PBefG) of 8 August 1990, BGBl I, 1690; sec 4(1) sentence 1 German Renewable Energy Act (EEG) of 21 July 2014, BGBl I, 1066, sec 6(1) German Energy Industry Act (EnWG) of 7 July 2005, BGBl I, 1970; see Ch. Armbrüster, in Erman BGB $\left(14^{\text {th }}\right.$ ed, Cologne: Schmidt, 2014) with sec 145 para 28.

83 See sec 20(6) German Restriction of Competition Act (GWB) and sec 33 in conjunction with sec 20(1), 2 GWB.

84 In addition to the RG (n 81 above) also the BGH, Judgment of 2 December 1974, II ZR 78/72, $B G H Z$ 63, 282, 285 - monopoly organisation's obligation to include; agreeing, W. Fikentscher and A. Heinemann, Schuldrecht (11 ${ }^{\text {th }}$ ed, Berlin: de Gruyter, 2017) para 113; also inclined this way, 
affirmed even without evidence of intent and immorality. ${ }^{85}$ Alternatively, an overall analogy to Article 1(1) and 20(1) GG was derived. ${ }^{86} \mathrm{~A}$ third approach seeks to draw an overall analogy to the provisions of the obligation to contract explicitly prescribed by law, and connect this to the welfare state principle in Article 20(1) GG. ${ }^{87}$ Legal concepts such as justice or legal certainty are too general to derive the obligation to contract from them. ${ }^{88}$

\section{b) On the disputed Price Control of Contracts - the laesio enormis}

aa) The reasonableness of benefit and consideration can be found as iustitia commutativa in Aristotle ${ }^{89}$ (Section 1 Paragraph 98) and also in its early stages in Roman law. ${ }^{90}$ In the Middle Ages, the equivalence principle then developed, which stated that benefit and consideration must be in reasonable proportion to one another. ${ }^{91}$ The prohibition on substantial injury (laesio enormis) entitles one side to cancel the contract when the agreed price accounts for less than half of the true value (iustum pretium). ${ }^{92}$ The prohibition of laesio enormis is paternalistic because it ignores the intentions of the contracting parties. Consequently, the modern codifications have not adopted the prohibition on laesio enormis. ${ }^{93}$ The

P. Bydlinski, 'Zu den dogmatischen Gurndfragen des Kontrahierungszwangs' Archiv für die civilistische Praxis 180 (1980) 1, 42 et seq.

85 J. Busche, in Münchener Kommentar zum BGB (MünchKomm-BGB) $\left(7^{\text {th }}\right.$ ed, Munich: C H Beck, 2015) with sec 145 para 21; Armbrüster, n 82 above, with sec 145 para 29.

86 Neuner, n 49 above, sec 48 para 13 and sec 10 para 45.

87 Ellenberger, $\mathrm{n} 58$ above, introduction to sec 145 para 10.

88 J. Busche, Privatautonomie und Kontrahierungszwang (Tübingen: Mohr Siebeck, 1999) 126. For a different view, L. Raiser, 'Der Gleichheitsgrundsatz im Privatrecht' Zeitschrift für das gesamte Handels- und Wirtschaftsrecht (ZHR) 111 (1948) 75, 93 et seq: 'substantive principle of justice'.

89 Aristotle, $\mathrm{n} 38$ above.

90 C 4.44.2; here, Ch. Becker, Die Lehre von der laesio enormis in der Sicht der heutigen Wucherproblematik (Cologne: Heymanns, 1993) 10 et seq; Zimmermann (1992, Law of Obligation), n 37 above, 259 et seq.

91 Decretales Gregorii P IX, Lib III, Tit XVII, Ch III; Azo, In ius civile summa (1564) Tit de rescindenda venditione No 4, 114: Venditor vel emptor quando censeatur deceptus ultra dimidiam iusti pretijThe vendor or purchaser, when he should be considered to be deceived by over half of the just price; Ch.F. von Glück, Ausführliche Erläuterungen der Pandekten, volume 17 (1815) 35 et seq.

92 It can even be found in older codifications such as the Codex Maximilianeus bavaricus civilis, the ALR, the ABGB and the Code Civil, IV part, $3^{\text {rd }} \mathrm{ch}$, sec 19 et seq CMBC; I part, sec 59, 69 ALR; sec 934 ABGB and art 1674 et seq cc: limited to 3/7 for land contracts; here Zweigert and Kötz, n 70 above, 320 .

93 So expressly, Motive, n 2 above, 321: 'The Draft [...] has removed the right to rescind the contract of sale due to so-called laesio enormis'. 
BGB does not have any general price controls, but rather requires that freedom of choice is impaired as a further prerequisite for the facts of usury to be established in Section 138(2) BGB.

bb) Nonetheless, the BGH frequently imposed price control in the past, eg when it declared the contract which sold a slot machine worth DM 30,000 for DM 80,000 to be immoral and thus void in the sense of Section 138(1) BGB. ${ }^{94}$ In another decision, the BGH declared a lawyer's flat-rate fee to be immoral because it exceeded the statutory fees five fold. ${ }^{95}$ With an objectively conspicuous disparity between benefit and consideration, the case law assumes intention to exploit ${ }^{96}$ and therefore circumvents the prerequisite in Section 138(2) BGB. In part, therefore, some refer to a 'renaissance of the laesio enormis' ${ }^{97}$ and there is discussion of contractual justice in the sense of an equivalence between benefit and consideration. ${ }^{98}$ How do these considerations now connect with the binding contract just formulated or the principle of private autonomy?

\section{c) Frustration of Contract and clausula rebus sic stantibus}

aa) There is a third legal doctrine, which softens the binding contract, the principle of pacta sunt servanda. The doctrine of clausula rebus sic stantibus means that any contract should only be binding as long as the circumstances that determined its conclusion have not radically changed. ${ }^{99}$ It experienced its heyday in modern

\footnotetext{
94 BGH, Judgment of 26 November 1997, VIII ZR 322/96, BetriebsBerater 1998, 393 - slot machine. 95 BGH, Judgment of 10 November 2016, IX ZR 119/14, Zeitschrift für Wirtschaftsrecht (ZIP) 2017, 2479 para 19 et seq - immorality of a fee agreement with commentary, V. Römermann, Entscheidungen zum Wirtschaftsrecht (EWiR) 2017, 45 et seq, which is critical of why even 5 times the amount should establish immorality.

96 BGH, Judgment of 10 July 1986, III ZR 133/85, BGHZ 98, 174, 178; BGH, Judgment of 19 January 2001, V ZR 437/99, BGHZ 146, 298, 302; Ch. Armbrüster, in MünchKomm-BGB , n 85 above, sec 138 para 154.

97 See the analyses of Th. Mayer-Maly, 'Renaissance der laesio enormis?', in Festschrift Larenz (Munich: C H Beck, 1983) 395, 398 et seq; Th. Finkenauer, 'Zur Renaissance der laesio enormis beim Kaufvertrag', in Festschrift Westermann (Berlin: de Gruyter, 2008) 183 et seq.

98 F.J. Säcker, in MünchKomm-BGB , n 85 above, introduction para 38: 'In my view, this case law can be generalised, such that agreements are invalid under Section 138(1) if they exceed the specific normal market price for a product or service in the relevant market by $100 \%$ or more.'.

99 It is already in the Codex Maximilianeus bavaricus civilis and in the ALR, and also in other legal codes, fourth part, $15^{\text {th }}$ ch sec 12 CMBC: 'and as [...] all bonds implicitly contain the Clausulam Rebus sic Stantibus'; first part, fifth title, sec 377-380 ALR; art 24(1) clause 4 and 373 Swiss OR and art 3571 of the Polish Civil Code.
} 
times. ${ }^{100}$ Due to its vagueness, the legislator had consciously not included the doctrine of clausula rebus sic stantibus in the BGB. ${ }^{101}$ Due to the massive inflation after the $1^{\text {st }}$ World War, however, the case law then made adjustments to contracts. Whereas the case law originally referred to impossibility ${ }^{102}$ or economic impossibility, ${ }^{103}$ it later recognised the doctrine from Oertmann ${ }^{104}$ of the basis of the transaction ceasing to exist ${ }^{105}$ and referred to good faith. ${ }^{106}$ English case law reacted in a similar way with the 'doctrine of frustration of the contract, ${ }^{107}$ while in Italy, the Netherlands, and Greece the legislator had to assist. ${ }^{108}$

bb) In the course of time, literature and case law have developed groups of cases such as disruption of equivalence, disruption of the intended purpose, joint error of motive, and similar factual conditions within an independent case group in Section 242 BGB. Firstly, the basis of the transaction must have substantially changed; secondly, the risk may not be borne unilaterally by one party. ${ }^{109}$ This

100 A. Leyser, Meditationes ad Pandectas (3 $3^{\text {rd }}$ ed, 1741) vol 1, specimen 40 IV, 411: 'Omne pactum, omnis promissio, rebus sic stantibus, intelligenda est'; Zimmermann (1992, Law of Obligation), n 37 above, 579 et seq. B. Windscheid, Die Lehre des römischen Rechts von der Voraussetzung (1850), then developed these further.

101 Motive, n 2 above, 249: 'currently does not have that structure and recognition'.

102 RG, Judgment of 6 July 1898, I 174/98, RGZ 42, 114, 116 et seq.

103 RG, Judgment of 23 February 1904, II 398/03, RGZ 57, 116, 118 et seq.

104 P. Oertmann, Die Geschäftsgrundlage (1921); P. Oertmann, 'Doppelseitiger Irrtum beim Vertragsschlusse' Archiv für die civilistische Praxis 117 (1919) 275 et seq.

105 RG, Judgment of 3 February 1922, II 640/21, RGZ 103, 328, 332 - Vigognespinnerei; RG, Judgment of 6 August 1923, II 215/23, RGZ 106, 422, 424 et seq; here K. Luig, in R. Zimmermann, Rechtsgeschichte und Privatrechtsdogmatik (Heidelberg: Müller, 1999) 171, 185 et seq; R. MeyerPritzl, in HKK-BGB, n 79 above, sec 313-314 para 18 et seq.

106 Even today, see BGH, Judgment of 25 February 1993, VII 24/92, BGHZ 121, 378, 391; Bundestag document no 14/6040, 174. But critical, W. Flume, Allgemeiner Teil des Bürgerlichen Rechts, volume II ( $4^{\text {th }}$ ed, Berlin: Springer, 1992) 500: 'In reality, however, there is nothing to be gained by referring to "good faith"'.

107 Taylor v Caldwell (1863) 3 B \& S 826, 122 ER 309, 312 [833] and the famous coronation case Krell v Henry (1903) LR 2 KB 740, 754. In the interim, the legislator responded with the Frustrated Contracts Act 1943 for England and sec 2-615(a) Uniform Commercial Code (UCC) for the USA.

108 Art 1467 et seq. Italian codice civile of 4 April 1942, in France there were only special provisions for specific problems, see M. Ferid and H.J. Sonnenberger, Das Französische Zivilrecht, volume 1 ( $2^{\text {nd }}$ ed, Heidelberg: Verlagsgesellschaft Recht und Wirtschaft, 1994) para $1 \mathrm{~F} 770,568$ et seq. In the interim, there are also provisions in art 388 Greek civil code, book 6 art 258 Dutch nieuw burgerlijk wetboek; art 1195 cc. See also art III-1:110 DCFR: change of circumstances.

109 Fundamentally, W. Fikentscher, Die Geschäftsgrundlage als Frage des Vertragsrisikos (Munich: C H Beck, 1971) 31 et seq, 107 et seq; E. Rabel, Das Recht des Warenkaufs, volume 1 (Berlin: de Gruyter, 1936) 357; Flume (1960), n 4 above, 208. See BGH, Judgment of 25 February 1993, VII 24/92, BGHZ 121, 378, 392; in detail Meyer-Pritzl, n 105 above, sec 313-314 para 61 et seq. 
needs a delineation of the parties' areas of risk. And thirdly, the change may not be one that could be reasonably be expected by the affected party. ${ }^{110}$ These features could then be consolidated into factual elements so that the legal doctrine could be incorporated into the BGB as Section 313 in 2002. ${ }^{111}$ But how can the frustration of contract be justified in legal doctrine? It clearly contradicts the principle of pacta sunt servanda. ${ }^{112}$

\section{The Right to Self-Determination as a Justification for various Legal Doctrines}

How can the various legal institutes be explained? To which legal principle can they be reduced? In this regard, the legal literature contains several views.

\section{Approaches in Literature}

\section{a) Private Autonomy and contractual Justice}

Schmidt-Rimpler represents the view that the negotiation of the essential components of the contract by both parties leads to the contract's 'guaranteed correctness'. ${ }^{113}$ However, this view is only partly convincing when stated so generally because self-determination on both sides is absent when there is an inequality of power. ${ }^{114}$ Thus, numerous voices criticised the lack of protection for the weak

110 K. Larenz, Geschäftsgrundlage und Vertragserfüllung, die Bedeutung 'veränderter Umstände' im Zivilrecht ( $3^{\text {rd }}$ ed, Munich: C H Beck, 1963); Th. Finkenauer, in Münchener Kommentar zum BGB (MünchKomm-BGB) (7 $7^{\text {th }}$ ed, Munich: C H Beck, 2016) sec 313 para 56; H. Köhler, 'Die Lehre von der Geschäftsgrundlage als Lehre von der Risikobefreiung', in 50 Jahre Bundesgerichtshof: Festgabe aus der Wissenschaft, volume 1 (Munich: C H Beck, 2000) 295, 297 et seq for a different view Flume, n 106 above, 520, who calls for intervention by the legislator in circumstances where equivalence is disrupted.

111 German Modernisation of the Law of Obligations Act (SMG) of 26 November 2001, $B G B l$ I 3138.

112 Fikentscher and Heinemann, n 84 above, para 224.

113 Schmidt-Rimpler (1941), n 67 above, 132 et seq, 152 et seq; Schmidt-Rimpler (1974), n 67 above, 3, 6 et seq; Lieb, $\mathrm{n} 67$ above, 206.

114 Against Schmidt-Rimpler, see Flume (1960), n 4 above, 142 et seq. C.-W. Canaris, Die Bedeutung der iustitia distributiva im deutschen Vertragsrecht (Munich: Verlag der Bayerischen 
when the BGB came into force. ${ }^{115}$ Many voices claimed a protection of the consumer for $\mathrm{s} /$ he is the weaker party. ${ }^{116}$ Contractual justice is the substantive operating principle of contract law. ${ }^{117}$ There are developments to this end in the case law when price controls are imposed and when the reasonableness of the contract is extrapolated from the price. The ruling of the BVerfG $^{118}$ on guarantee agreements of family members was also accused of not clarifying the extent to which controls on contracts would be permitted under concepts such as 'disrupted contractual parity' or 'unequal situation'. ${ }^{119}$ Contractual justice must be rejected because the BGB does not provide for any generalised control of the content of contracts. ${ }^{20}$ However, situations of imbalance are still not sufficient in their own right to justify price control.

\section{b) Private Autonomy as an Optimisation Requirement}

It is to some extent asserted that private autonomy would be an optimisation requirement which, as with other legal principles, is restricted by other legal principles. ${ }^{121}$ Raiser ${ }^{122}$ and subsequently Neuner ${ }^{123}$ develop a principle of the social, based on the constitution, which can restrict freedom of contract. In

Akademie der Wissenschaften, 1997) 49: 'only a prospect of correctness'; L. Fastrich, Richterliche Inhaltskontrolle im Privatrecht (Munich: C H Beck, 1992) 52 et seq.

115 O. von Gierke, Der Entwurf des Bürgerlichen Gesetzbuchs und das deutsche Recht (1889) 192; A. Wagner, Grundlegung der politischen Ökonomie, $2^{\text {nd }}$ part ( $3^{\text {rd }}$ ed, 1894) 99 et seq; A. Menger, Das bürgerliche Recht und die besitzlosen Volksklassen (1886) 26, 153 et seq.

116 See here S. Atiyah, 'Contract and fair exchange' 35 University of Toronto Law Journal 1, 14 et seq (1985); S. A. Smith, Atiyah's Introduction to the Law of Contract ( $6^{\text {th }}$ ed, Oxford: Clarendon Press, 2005) 297.

117 See K. Zweigert and H. Kötz, Einführung in die Rechtsvergleichung ( $2^{\text {nd }}$ ed, Tübingen: Mohr, 1984) 7 et seq.

118 BVerfG, decision of 19 October 1993, 1 BvR 567/89 inter alia, BVerfGE 89, 214, 231 et seqguarantee contracts.

119 Critical W. Zöllner, 'Regelungsspielräume im Schuldvertragsrecht' Archiv für die civilistische Praxis 196 (1996) 1, 26 et seq, 30; D. Coester-Waltjen, 'Die Inhaltskontrolle von Verträgen außerhalb des AGBG’ Archiv für die civilistische Praxis 190 (1990) 1, 23.

120 J. Drexl, Die wirtschaftliche Selbstbestimmung des Verbrauchers (Tübingen: Mohr Siebeck, 1998) 208; K. Ritgen, 'Vertragsparität und Vertragsfreiheit' JuristenZeitung 2002, 114, 119; S. Hofer, Vertragsfreiheit am Scheideweg (Munich: C H Beck, 2006) 23.

121 Neuner, $\mathrm{n} 49$ above, sec 10 para 30.

122 L. Raiser, 'Vertragsfreiheit heute' JuristenZeitung 1958, 1, 6, 8.

123 J. Neuner, Privatrecht und Sozialstaat (Munich: C H Beck, 1999) 237 et seq; Neuner, n 49 above, sec 10 para 42 et seq. 
addition to the obligation to contract, it should also include information requirements (such as the instructions on cancellation in Section 355(2) BGB) or the protection against lack of perspective. For these observations, it can be stated that the legislator and the case law in the last decades developed the market economy into a social ${ }^{124}$ or environmental-social market economy; ${ }^{125}$ the extensive legislation in the fields of occupational safety, rental and consumer protection law serve as proof for this thesis.

However, two considerations indicate otherwise. The principle of the social does not concern an optimisation of freedom of contract, but rather the preservation of a minimum level of freedom of contract for the parties. The optimisation concept suggests that freedom of contract, as with the fundamental rights in public law, has to be balanced with other rights and brought into a proportional practical concordance. However, such a concept of balancing cannot be found in German private law. ${ }^{126}$ In general, state restraint is required. This accords with the fundamental liberal ideas of the BGB. As long as the contract is within a certain tolerable framework the state may not make directive interventions. It is only when the degree of injustice breaks through these boundaries that the parties' power of determination transfers to the state. Moreover, fundamental rights only act indirectly between private actors, eg for the theatre critic, the right to freedom of expression and freedom of the press. ${ }^{127}$ It is only for racially-motivated discrimination that one can appeal to human dignity directly from the GG, ${ }^{128}$ but not for the refused journey to the airport. ${ }^{129}$ The Basic Law is frequently too vague to derive entitlements from it. ${ }^{130}$ To justify the journey to the airport, or the desire to open a current account with human dignity or the welfare state principle, without

124 Möllers, $\mathrm{n} 62$ above, 1192 et seq.

125 Thus the writings of W. Fikentscher, Die umweltsoziale Marktwirtschaft (Heidelberg: Müller, 1991).

126 On the discussion, see in detail Möllers, $\mathrm{n} 60$ above, sec 12 para 93 et seq.

127 R. Bork, in Staudinger, BGB (Neubearb, Berlin: Sellier-de Gruyter, 2015) with sec 145-156 para 23; Neuner, n 49 above, sec 48 para 14. But for a different view, RG, Judgment of 7 November 1931, V 106/31, RGZ133, 388, 392 -theatre critic, $\mathrm{n} 81$ above.

128 Möllers, $n 60$ above, sec 7 para 12.

129 It is not the case that any lack of objectivity is discriminatory, similarly Bork, $n 4$ above, para 671 .

130 Critical of Neuner's approach, Rückert, n 37 above, with sec 1 para 107 fn 375: 'improper attempt to formulate free and social as being generally opposed.'; similarly against returning to the principle of the social market economy, H. Bartholomeyczik, “Äquivalenzprinzip, Waffengleichheit und Gegengewichtsprinzip in der modernen Rechtsentwicklung’ Archiv für die civilistische Praxis 166 (1966) 30, 49. 
a legal basis, would be to use a sledgehammer to crack a nut. ${ }^{131}$ The principle of the social promises too much, but it cannot be about ensuring justice, but rather only preventing gross injustices. One's priority should therefore be to attempt to justify the legal doctrine directly with the legal principles of private law and not with the constitution.

\section{c) Further Approaches to justify Private Autonomy}

Legal literature subdivides private autonomy into self-determination, personal responsibility, and protection of legitimate expectations. ${ }^{132}$ As attribution criteria, that may be sufficient for a dynamic system. Nevertheless, this does not explain the determinative element of private autonomy yet. Rückert names the principle equal legal freedom. ${ }^{133}$ It was certainly one of the big achievements to overcome the hierarchical society of the $19^{\text {th }}$ century. However, the principle in its generality seems to be more of a legal concept than a legal principle. Moreover, when private autonomy and freedom of contract are to some extent equated in legal literature, ${ }^{134}$ this is not convincing for the groups of cases referred to.

\section{Private Autonomy as Self-Determination for both Parties}

\section{a) Self-Determination of the individuals and mutual Self-Determination}

aa) The presentation of the legal doctrine above emphasises freedom of contract too much. This neglects the essential element of self-determination. Self-determination is a prerequisite for freedom of contract. The following wording is already contained in the Motive: 'The legal system cannot allow free self-determination to be impaired in legal transactions in an unlawful way. ${ }^{\prime 35}$ In addition, the first sentence in Flume's work 'Rechtsgeschäft' reads: 'Private autonomy is the name given to the principle of self-organisation of legal relationships by the individual

131 But Neuner, n 49 above, sec 48 para 13 and sec 10 para 45; Ellenberger, n 58 above, introduction to section 145 para 10.

132 Canaris, $\mathrm{n} 15$ above, 50 et seq.

133 Rückert, $n 37$ above, with sec 1 para 39 et seq, 47, 86 et seq.

134 See Flume, n 106 above, 12; S. Lorenz, Der Schutz vor dem unerwünschten Vertrag (Munich:

C H Beck, 1997) 17; Busche, n 88 above, 13.

135 Motive, n 2 above, 204. 
according to his/her will. ${ }^{136} \mathrm{He}$ continued verbatim: 'For as far as self-determination reaches, there is no external control. The deliberate decision is valid because it is intended and the will of the individual is respected as such. Private autonomous organisation requires, insofar as it is recognised by law, no justification other than the individual intends. ${ }^{137}$

$\mathrm{bb}$ ) Self-determination is often only referred to in relation to one party to the contract. ${ }^{138}$ However, the principle of self-determination apparently applies to both sides. Self-determination of both sides also means protection against external control. ${ }^{139}$ Flume justifiably emphasises that the contract requires mutual selfdetermination and that an inequality of power or factual monopoly position leads to one-sided external control. The concept of mutual self-determination as part of private autonomy was met with approval. ${ }^{140}$ Flume had already stated the following in 1960:

'Insofar as individuals are provided with the right to regulate legal relationships by mutual self-determination, that is, by contract, in our legal system, it is based on the requirement that the individuals face one another with the power of self-determination, and do not enter into them by the power of one-sided external control instead of mutual self-determination. Compulsion and private autonomy are incompatible with one another. However, it is private autonomy's eternal dilemma that it is continually brought into question by an unequal distribution of power.' ${ }^{141}$

\section{b) Derivation of the Principle of Self-Determination from the BGB and the Constitution}

This principle can be discerned from an indirect third-party effect of the fundamental rights. In the decision on the guarantee for asset-less relatives, the BVerfG stressed that Article 2(1) GG guarantees the 'self-determination of the individual

136 Flume, n 106 above, 1; as above Flume (1960), n 4 above, 136 et seq, 143; agreeing Canaris, n 4 above, 277; Bork, n 4 above, para 99; Rückert, n 37 above, with sec 1 para 108 speaks of 'drumbeat'. See also BVerfG, decision of 13 May 1986, 1 BvR 1542/84, BVerfGE 72, 155, 170.

137 Flume (1960), n 4 above, 141.

138 Busche, n 85 above, with sec 145 para 6 and the evidence in sec 12 fn 144; Neuner, n 49 above, sec 10 para 30 .

139 N. Reich, 'Das Phantom «Verbraucherrecht» - Erosion oder Evolution des Privatrechts?' JuristenZeitung 1997, 609.

140 Säcker, n 98 above, introduction para 37.

141 Flume (1960), n 4 above, 143; similarly K. Larenz, Schuldrecht, volume 1 (14 $^{\text {th }}$ ed, Munich: C H Beck, 1987) sec 4, 41: 'free self-determination of each of the two contracting parties'. 
in legal life ${ }^{142}$ as part of private autonomy, and required an understanding of private autonomy in several decisions, when there would have been a 'structural inequality of bargaining power' or a 'disrupted contractual parity'. ${ }^{143}$ In terms of a constitution-oriented (reinforcing) interpretation, there is nothing to preclude this. $^{144}$

However, it is more convincing to interpret the principle of self-determination as part of the private autonomy of both parties and thus as a private law legal principle. The BGB expresses this principle through the will theory of the $19^{\text {th }}$ century, which is standardised in Section 133 ('to ascertain the true intention'), the mistake rules (Section 119 et seq). Self-determination is also guaranteed in family and probate law. ${ }^{145}$ Seen historically, the BGB did not only want to introduce freedom, but also an equal legal freedom ${ }^{146}$ without differentiation between persons. Through European law, the German legislator also added the cancellation (Section 312 BGB), which strengthened the self-determination of the consumer. Equal legal freedom thus means the equal use of freedom for all.

\section{c) Restriction of Self-Determination which restricts Freedom as the substantiating Standard for Correction of the Contract}

Initially, it generally adheres to freedom of contract with its variants. If one concedes the self-determination of both sides, it can, in certain cases, lead to a need for external control to be corrected. In the first instance, that justifies procedural equality of arms. ${ }^{147}$ Self-determination therefore requires protection against procedural defects which arise, inter alia, from fraud or duress. The right of self-determination is thus not only a principle to justify the binding nature of contracts, but can also correct the binding contract in cases of doubt. If the parties have bound themselves contractually in a self-determined manner in the first

142 BVerfG, decision of 19 October 1993, 1 BvR 567 inter alia, BVerfGE 89, 214, 231 - guarantee agreements referring to Erichsen, see H.-U. Erichsen, in J. Isensee an P. Kirchhof (eds), Handbuch des Staatsrecht, volume VI (Heidelberg: Müller, 1989) sec 152 para 58 et seq, which in fn 195, 197, again refers to Flume (1960), n 4 above, 143.

143 Moreover, it referred to the welfare state principle (art 20(1), 28(1) sentence $1 \mathrm{GG}$ ), see BVerfGE 89, 214, 231 et seq - guarantee agreements.

144 Möllers, n 60 above, sec 7 para 73.

145 Sec 1821, 1822 in conjunction with 1643 BGB; sec 1901(1) sentence 2 BGB; sec 2064 BGB.

146 Rückert, n 37 above, with sec 1 para 43 et seq, who speaks of a principle of equal legal freedom; agreeing Hofer, n 120 above, 11.

147 In the ruling over a guarantee of a family member BVerfGE 89, 214, 232 this is already found in the guiding principle in the concept of 'inequality of bargaining power'. 
place, the hurdles for correction of the contract are all the higher. Thus, there is no (subsequent) control of reasonableness in the sense of equitable outcomes (see right below). The guideline must be the principle that it is not justice, but rather only injustice which can be the standard for a legal intervention. ${ }^{148}$ This evokes the controls on law and regulations through the Radbruch formula. ${ }^{149}$ In the words of the BVerfG, it is necessary that the consequences for the losing party are 'exceptionally onerous' ${ }^{150}$ and therefore evidently one-sided. ${ }^{151}$ This theory of the materialisation of freedom of contract, which reflects on the self-determination of the individual in the sense of Flume and the BVerfG, is no threat to the private law company, but is rather a logical development and improvement. ${ }^{152}$ It must be decisive that the self-determination acts to restrict freedom, thus gains a certain weight. This can now be further substantiated for the three legal doctrines discussed.

\section{The doctrinal Legal Justification of the various Legal Doctrines where the Right of Self-Determination is absent}

\section{a) Obligation to Contract and lack of Self-Determination}

The obligation to contract can be justified by private autonomy itself. At first glance, the obligation to contract is opposed to freedom of contract because one side loses the freedom to conclude contracts referred to above. ${ }^{153}$ However, that is only applicable when one only considers the opposing party to the contract, the party refusing to accept, in isolation. Freedom of contract, however, is a conditioned freedom which is aimed at fulfilling mutual interests. If freedom of contract includes the self-determined decision of both sides, then private autonomy also allows the freedom to form a contract and thus the right, under certain conditions,

148 C.-W. Canaris, 'Verfassungs- und europarechtliche Aspekte der Vertragsfreiheit in der Privatrechtsgesellschaft', in Festschrift Lerche (Munich: C H Beck, 1993) 873, 883 et seq; Neuner, n 49 above, sec 10 para 30.

149 G. Radbruch, 'Gesetzliches Unrecht und übergesetzliches Recht' Süddeutsche JuristenZeitung 1946, 105, 107.

150 BVerfG, decision of 19 October 1993, 1 BvR 567, 1044/89, BVerfGE 89, 214, 232 - guarantee agreements.

151 Ritgen, n 120 above, 119; Hofer, n 120 above, 23.

152 Drexl, n 120 above, 208, 296; on Flume (1960), n 4 above, 143, on the BVerfG (fn 150). For a different view, expressly Zöllner, $\mathrm{n} 119$ above, 24 et seq.

153 Flume, n 106 above, 611; Neuner, n 123 above, 287: 'because it hereby involves the opposite of self-determined legal consequences'. 
to force conclusion of a contract. Freedom of contract is impaired when there is no choice. ${ }^{154}$ The reliance on the service clarifies, when there is an obligation to contract, ${ }^{155}$ the lack of self-determination. The self-determination of the party wishing to contract is severely restricted in the absence of alternatives, such that the self-determination of the other party is, by way of exception, restricted. The obligation to conclude a contract in this respect establishes a legal obligation which includes the obligation to give a declaration of intent aimed at the conclusion of a contract. ${ }^{156}$

\section{b) Price Controls under Section 138(1) BGB for Contracts which intervene in the self-determined Life with severe freedom-restricting Consequences}

aa) Formally, the judgments on price controls ${ }^{157}$ are not convincing because the presumption of a reprehensible attitude in the event of a disparity between benefit and consideration only constitutes an apparent justification ${ }^{158}$ and fiction. ${ }^{159}$ In terms of content, such judgments are in contrast with the BGB. The wording of Section 138(2) BGB requires, along with the need for a conspicuous disparity, also exploitation of plight and therefore does not directly provide any general price controls. It is thereby fundamentally left to the contracting parties to determine the content and extent of the essential components of the contract (essentialia negotii) and so to specify the price. Moreover, it would be systematically inconsistent if an unlawful threat or a fraudulent deception were 'only' to lead to a right to avoid a contract, but a particularly large disparity in benefit would lead ipso iure to invalidity under Section 138 BGB. ${ }^{160}$ Furthermore, it would be counterproductive if anyone were to be able to rely on judicial price control. The consequence would be a multitude of imprudent contracts. ${ }^{161}$

154 Thus J. Kohler, Lehrbuch der Rechtsphilosophie (1909) 96. Busche, n 88 above, 125 et seq, in addition to the legally protected interests, mentions the dependence on the provider.

155 Fastrich speaks of 'existential dependence', n 114 above, 232 et seq. On dependence, see Schmidt-Rimpler (1941), n 67 above, $157 \mathrm{fn} 34$.

156 Armbrüster, $\mathrm{n} 82$ above, with sec 145 para 31.

157 See above fn 94 et seq.

158 H. Koziol, 'Sonderprivatrecht für Konsumentenkredite?' Archiv für die civilistische Praxis 188 (1988) 183, 207.

159 Th. Mayer-Maly, Das Bewußtsein der Sittenwidrigkeit (Karlsruhe: Müller, 1971) 12; MayerMaly, n 97 above, 400, 404 et seq; Th. Finkenauer, n 97 above, 183, 193.

160 M. Maßß, 'Grundstückskauf nur noch mit Wertgutachten?' Neue Juristische Wochenschrift 2001, 3467, 3468; Finkenauer, n 97 above, 205.

161 Bartholomeyczik, n 130 above, 62. 
bb) According to the view represented here, simple contracts of sale or contracts of service are not subject to the immorality and price control of Section 138 BGB. ${ }^{162}$ Instead of employing an immorality review of the relevant market, however, the breach of a duty to inform ${ }^{163}$ or fault in conclusion of the contract (culpa in contrahendo) can intervene in such a case. ${ }^{164}$ The BGH therefore correctly rejected immorality when a purchaser had acquired collector's coins at a price of DM 20,000, and could then only resell them for the value of the metal at DM 2,250. ${ }^{165}$ The market and not the judge fundamentally determines the reasonableness of the price.

cc) Situations of imbalance can only be relevant when the consequences are exceptionally onerous and that self-determination is therefore massively impaired. ${ }^{166}$ Contracts restrict the self-determined life when they act to severely restrict freedom. It is not justice, but rather injustice which is the standard for a legal intervention. The exploitation of a position of power or the restriction of freedom are also recognised as grounds for attribution within the general clause in Section 138 BGB. After conclusion of the contract, one can include cases of loss of perspective ${ }^{167}$ or the restriction of freedom in existential areas of life. ${ }^{168}$ Case law has already developed groups of cases. For transactions of existential importance, exceptionally, there is price control. In German law, this is relevant for rent, the purchase of property, or wages. ${ }^{169}$ Self-determination, thus, does not only refer to the exercise of a declaration of intent, but rather also the selfdetermined life which should ensure that the wage is generally sufficient to live on, that tenancy law protects the tenant's social environment, and the purchase

162 Also opposed, Mayer-Maly, n 97 above, 395, 398 et seq; Finkenauer, n 97 above, 183 et seq; Rückert, n 37 above, with sec 1 para 112.

163 Thus P. Singer, Comment on BGH, Judgement of 22 December 1999, VII ZR 111/99, JuristenZeitung 2001, 195, 197 against the opinion of the BGH collector's coin, next note.

164 BGH, Judgment of 22 December 1999, VIII ZR 111/99, Neue Juristische Wochenschrift 2000, 1254, 1255 - collector's coin.

165 BGH, Judgment of 22 December 1999, VIII ZR 111/99, Neue Juristische Wochenschrift 2000, 1254, 1255 - collector's coin. The hire purchase of pool/billiards equipment at 2.5 times the value was also not immoral, BGH, Judgment of 24 January 1979, VIII ZR 16/78, Wertpapier-Mitteilungen 1979, 491, 492. See also above, fn 65.

166 See fn 120.

167 For a different view, however, Neuner, n 49 above, sec 10 para 55 et seq, which understands this as 'immaterial property rights of the social principle'.

168 W. Enderlein, Rechtspaternalismus und Vertragsrecht (Munich: C H Beck, 1996) 293 et seq.

169 Similar examples in Neuner, n 49 above, sec 46 para 52. 
of a immorally inflated property does not drive the purchaser into the modern debtors' prison. ${ }^{170}$

\section{c) A freedom-restricting Lack of Equivalence as Frustration of Contract}

The requirements and groups of cases of frustration of contract were developed inductively within 80 years. Two key features are crucial. The background is, on the one hand, again the observation that courts cannot and should not review equivalence with frustration of contract. On the other hand, an adjustment can be made to the contract in extreme circumstances only, namely, situations which were not discernible for the contracting parties on conclusion of the contract and which massively disrupt the balance of the contract. ${ }^{171}$ Justice is thus specified as a legal concept through the principle of self-determination. This specifies the prerequisites of frustration of contract. The disruption may not fall within one of the contracting parties' areas of risk. In the event of a disruption of equivalence, it requires that the sphere of freedom is existentially impaired. It concerns cases which are simply incompatible with law and justice. ${ }^{172}$ The disruptions of equivalence must therefore clearly be more than $50 \%$ of the market price ${ }^{173}$ and again have severely restrictive impacts on freedom.

170 A debtors' prison was a private prison until the late Middle Ages and then a public prison for people who had not fulfilled their payment obligations, S. Breßler, Schuldknechtschaft und Schuldturm (Berlin: Duncker \& Humblot, 2004) 88, 115 et seq.

171 Bundestag document no 14/6040, 176: 'gross disparity with the creditor's interest in performance', C.-W. Canaris, 'Die Reform des Rechts der Leistungsstörungen' JuristenZeitung 2001, 499, 502. See BGH, Judgment of 25 February 1993, VII 24/92, BGHZ 121, 378, 393: 'when it concerns such a drastic change that adherence to the original provision would lead to an intolerable outcome which can plainly no longer be reconciled with law and justice, and adherence to the original contractual provision would therefore be unreasonable for the affected party'. Similarly Weller, n 65 above, 298 et seq.

172 Thus the formulation in H. Eidenmüller, 'Der Spinnerei-Fall: Die Lehre von der Geschäftsgrundlage nach der Rechtsprechung des Reichsgerichts und im Lichte der Schuldrechtsmodernisierung' Jura 2001, 824, 829; see fn 148.

173 Devaluation by more than $60 \%$, see BGH, Judgment of 18 September 1992, V 116/91, BGHZ 119, 220, 222 - increase in the ground rent; on this group of cases see H. Kötz, Vertragsrecht ( $2^{\text {nd }}$ ed, Tübingen: Mohr Siebeck, 2012) para 1014 et seq. 


\section{The Substantiation and Justification of Legal Doctrines through the Principle}

In terms of doctrinal legal analysis, the legal doctrines just mentioned could be explained by the principle of self-determination. The principle of self-determination can thereby justify the legal doctrines developed by the case law, even though they initially militate against the principles of freedom of contract and the binding contract. In a first step, the legal principle can be derived inductively. In a second step, however, the principle of self-determination also helps to deductively specify the legal doctrine. For example, it also shows limits for price control and frustration of contract. Eventually, the legal concept of justice also helps to state the prerequisites of the legal doctrine more precisely. This principle of selfdetermination can be illustrated graphically:

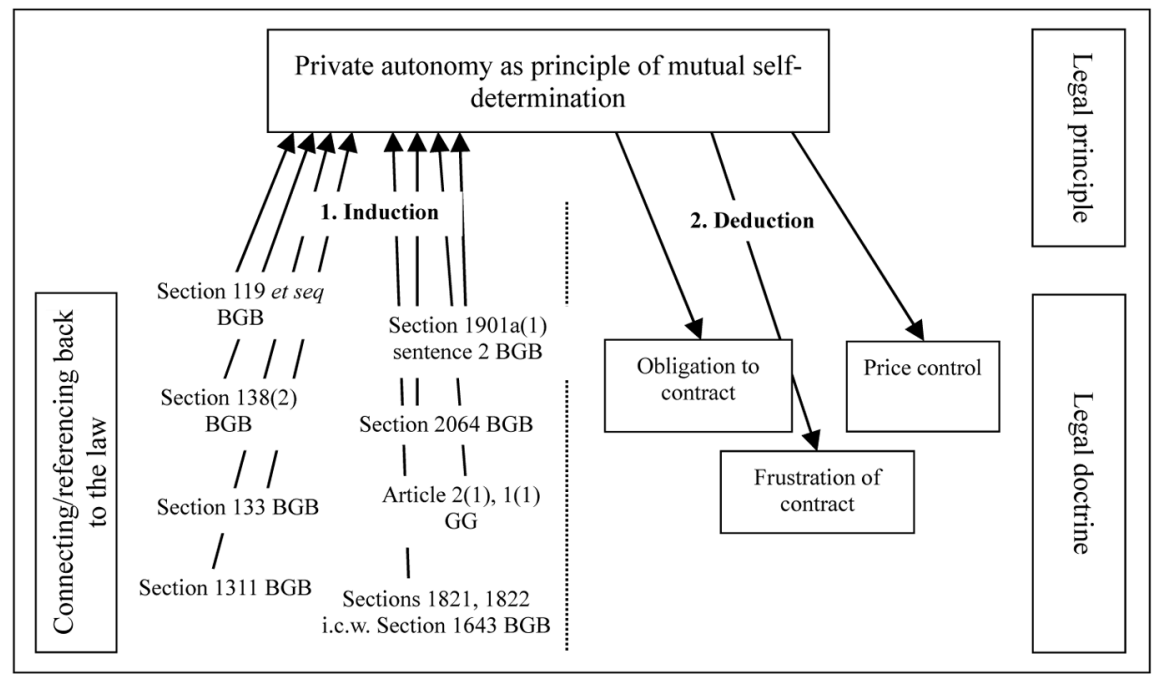

Graphic: Principle of self-determination and legal doctrines 


\section{Formation of Principles at the European Level}

\section{Extraction of Principles through Comparative Law}

When looking for principles at the European level, a distinction should be made between the general principles of primary law, which have priority in cases of doubt, and the principles of European private law, which have no force of precedence whatsoever and can (only) be used in the context of teleological considerations. ${ }^{174}$

\section{a) Reference to the General Principles of law or Constitutional Traditions of the Member States}

General principles of law also serve to fill in gaps in European law. Reference is often made to the general principles of law which are common to the legal systems - for example the liability of the Union, Article 340 TFEU. By reference to provisions of the national Member States, the CJEU can form a general rule from various provisions by induction. ${ }^{175}$ By reference to the constitutional traditions common to the Member States, the CJEU has developed fundamental rights at a European level, ${ }^{176}$ now standardised in Article 6(3) TEU, ${ }^{177}$ and established the claim for State liability against the Member States. The court has always emphasised that general principles have to fulfil a duty of developing law. ${ }^{178}$ Meanwhile, at the European level, in addition to recognising fundamental rights, it has also recognised general principles of law $^{179}$ such as legal cer-

174 B. Heiderhoff, Europäisches Privatrecht ( $4^{\text {th }}$ ed, Heidelberg: Müller, 2016) para 230.

175 For European law, A. Metzger, Extra legem, intra ius: Allgemeine Rechtsgrundsätze im Europäischen Privatrecht (Tübingen: Mohr Siebeck, 2009) 25 et seq; J. Basedow, 'Mangold, Audiolux und die allgemeinen Grundsätze des europäischen Privatrechts', in Festschrift Hopt (Berlin: de Gruyter, 2010) 27, 35.

176 ECJ, Judgment of 14 May 1974, 4/73, ECLI:EU:C:1974:51, ECR 1974, 491, para 13 - Nold.

177 Meanwhile, however, the fundamental rights were derived broadly from the Charter of Fundamental Rights of the European Union art 6(1) TEU.

178 ECJ, Judgment of 5 March 1996, C-46/93 inter alia, ECLI:EU:C:1996:79, para 27 - Brasserie du Pêcheur: Reference to 'the fundamental principles of the Community legal system and, where necessary, general principles common to the legal systems of the Member States.'; here F.-Ch. Schroeder, 'Die Auslegung des EU-Rechts' Juristische Schulung 2004, 180, 183 et seq.

179 Generally on the integration of general legal principles in European case law: P. Häberle, 'Gemeineuropäisches Verfassungsrecht' Europäische Grundrechte-Zeitschrift 1991, 261 et seq; 
tainty ${ }^{180}$ and protection of legitimate expectations, ${ }^{181}$ effective legal protection, ${ }^{182}$ effet utile, and proportionality. ${ }^{183}$

Interestingly, the CJEU to some extend gives the citizens stronger legal protection than the fundamental rights of individual Member States, since it developed the European fundamental rights and general principles of law. For example, broadly beyond the case law of German courts, the CJEU strengthened equal rights and particularly women's rights. This did not only happen with regard to the level of wage entitlement, but rather also with regard to access to and obtaining employment. ${ }^{184}$ With respect to procedural law, the CJEU has repeatedly stressed that access to the national courts must be guaranteed, ${ }^{185}$ and with this principle of effective legal protection restricted the procedural autonomy

P.-Ch. Müller-Graff and E. Riedel (ed), Gemeinsames Verfassungsrecht in der Europäischen Union (Baden-Baden: Nomos, 1998).

180 ECJ, Judgment of 21 September 1983, 205/85 inter alia, ECLI:EU:C:1983:233, para 30 - Milchkontor; ECJ, Judgment of 13 February 1996, C-143/93, ECLI:EU:C:1996:45, para 27 - Van Es Douane Agenten; ECJ, Judgment of 21 February 2006, C-255/02, ECLI:EU:C:2006:121, para 72 - Halifax.

181 ECJ, Judgment of 5 July 1973, 1/73, ECLI:EU:C:1973:78, para 6 et seq - Westzucker; ECJ, Judgment of 10 September 2009, C-201/08, ECLI:EU:C:2009:539, para 46 - Plantanol.

182 ECJ, Judgment of 15 May 1986, 222/84, ECLI:EU:C:1986:206, para 18 - Johnston; confirmed as an inherent principle in ECJ, Judgment of 13 March 2007, C-432/05, ECLI:EU:C:2007:163, para 37 et seq-Unibet.

183 ECJ, Judgment of 16 July 1956, 8/55, ECLI:EU:C:1956:11 = ECR 1955/1957, 197, 311 - Fédération Charbonnière; ECJ, Judgment of 13 December 1979, 44/79, ECLI:EU:C:1979:290, para 23 Hauer; P. Craig and G. de Búrca, EU Law (6 ${ }^{\text {th }}$ ed, Oxford/New York: Oxford University Press, 2015) 15.4(b), 551 et seq; U. Kischel, 'Die Kontrolle der Verhältnismäßigkeit durch den Europäischen Gerichtshof' Europarecht 2000, 380 et seq; O. Koch, Der Grundsatz der Verhältnismäßigkeit in der Rechtsprechung des Gerichtshofs der Europäischen Gemeinschaften (Berlin: Duncker \& Humblot, 2003); J.A. Frowein, 'Die Herausbildung europäischer Verfassungsprinzipien', in Festschrift Maihofer (Frankfurt/Main: Klostermann, 1988) 149, 151; M. Zuleeg and S. Kadelbach, in R. Schulze, M. Zuleeg and S. Kadelbach, Europarecht ( $3^{\text {rd }}$ ed, Baden-Baden: Nomos, 2015) sec 8 para 42 et seq. The legal competence for the principle of proportionality is found in art 5(4) TEU.

184 ECJ, Judgment of 14 December 1995, C-317/93, ECLI:EU:C:1995:438, para 28 - Nolte; ECJ, Judgment of 11 November 1997, C-409/95, ECLI:EU:C:1997:533, para 31 with approving comments, T. Lenz, Neue Juristische Wochenschrift 1998, 1619 - Marschall; S. Prechal, 'Combatting indirect discrimination in community law context', 20 Legal Issues of European Integration 81 et seq (1993). On the influence of the ECJ on the German Federal Labour Court (BAG) concerning impermissible questions regarding a pregnancy by the ECJ, Judgment of 8 November 1990, C-177/88, ECLI:EU: C:1990:383, ECR 1990, I-3941 para 24 et seq - Dekker; see BAG, Judgment of 15 October 1992, 2 AZR 227/92, BAGE 71, 252, 255.

185 ECJ, Judgment of 15 October 1987, 222/86, ECLI:EU:C:1987:442, para 14 - Heylens; ECJ, Judgment of 13 December 1991, C-18/88, ECLI:EU:C:1991:474, para 34 - GB-Inno-BM. 
of the Member States. ${ }^{186}$ The European Court of Human Rights has, for example, set higher standards for the requirement for timely legal protection than the national courts, and therefore declared proceedings of lengthy duration to be unlawful. ${ }^{187}$

\section{b) Isolated Codification of European Legal Principles}

Meanwhile, the European legislator has stated individual fundamental rights in the EU Treaty, as amended by the Amsterdam Treaty, and included the 1950 European Declaration of Human Rights, Article 6 TEU. Otherwise, legal principles (General Principles of Law), as with in the BGB, are also only tenuously standardised in the European Treaties. This is due to the fact that most principles were first developed by the CJEU before they then found their way into the law. In the TEU for example, one can find the principle of conferral and the principle of subsidiarity, Article 5(1)-(3) TEU or the principle of proportionality, Article 5(4) TEU. However, it is recognised that there are other additional principles, such as the principle of democracy (Article 2 TEU).

\section{General Legal Principles of European Private Law from the Classification of European Law}

\section{a) Difficulties at the European Level}

In an attempt to extract general legal principles from primary and secondary European law, various disadvantages become evident. Firstly, numerous principles are not standardised at all; secondly, entire areas of law are also only

186 R. Iglesias, 'Zu den Grenzen verfahrensrechtlicher Autonomie der Mitgliedstaaten bei der Anwendung des Gemeinschaftsrechts' Europäische Grundrechte-Zeitschrift 1997, 289, 290; R. Scholz, 'Zum Verhältnis von europäischem Gemeinschaftsrecht und nationalem Verwaltungsverfahrensrecht' Die Öffentliche Verwaltung 1998, 261, 262 et seq; C.M. Kakouris, 'Do the member states possess judicial procedural «autonomy»?' 34 Common Market Law Review 1389, 1407 et seq (1997); A. Cahn, Comment on EuGH, Judgements of 14 December 1995, C-430/93, C-431/93, C-312/ 93, Zeitschrift für Europäisches Privatrecht 1998, 969, 975.

187 J.A. Frowein, in W. Peukert and J.A. Frowein, Europäische MenschenRechtsKonvention: EMRK-Kommentar ( $3^{\text {rd }}$ ed, Kehl am Rhein: Engel, 2009) art 6 para 248 et seq with further citations. On the requirement for effective legal protection as a common constitutional tradition, see ECJ, Judgment of 13 March 2007, C-432/05, ECLI:EU:C:2007:163, para 37 et seq-Unibet. 
selectively regulated at the European level ${ }^{188}$ and thirdly, there is a danger that the European Union exceeds its competence by extracting a principle, and thus violates the principle of conferral, Article 5(2) TFEU. ${ }^{189}$ Finally, the risk of exporting one's own prior understanding must be avoided. Instead, European law must be interpreted autonomously, ${ }^{190}$ meaning independent of national understandings. As a consequence of this, the objectives at the European level are not absolutely identical to the objectives in one's own Member State.

It is also interesting to note the attempt to develop a European Civil Code, for example the Draft Common Frame of Reference - DCFR ${ }^{191}$ from various research groups, or the (withdrawn) proposal of the Commission for a Common European Sales Law - CESL. ${ }^{192}$ Some principles and rules, also known in German law, are already included in these drafts for European law. ${ }^{193}$ However, these are all still legally non-binding.

188 Rittner, 'Das Gemeinschaftsprivatrecht und die europäische Integration' JuristenZeitung 1995, 849, 851: 'An island in the sea of national law'; H. Kötz, 'Rechtsvereinheitlichung - Nutzen, Kosten, Methoden, Ziele’ Rabels Zeitschrift für ausländisches und internationales Privatrecht 50 (1986) 1, 5 'pointillist character'; Th. Möllers, book review of 'K. Riesenhuber, System und Prinzipien des Europäischen Vertragsrechts' JuristenZeitung 2004, 1067 et seq.

189 Critical, eg M. Schmidt-Kessel, in K. Riesenhuber, Europäische Methodenlehre ( ${ }^{\text {rd }}$ ed, Berlin: de Gruyter, 2015) sec 17 para 43.

190 ECJ, Judgment of 27 January 2005, C-188/03, EU:C:2005:59, para 29 - Junk; ECJ, Judgment of 12 February 1974, C-152/73, EU:C:1974:13, para 5 - Sotgiu; ECJ, Judgment of 3 July 1986, 66/85, EU: C:1986:284, para 26 et seq - Lawrie-Blum; ECJ, Judgment of 2 July 1996, C-473/93, EU:C:1996:263, para 26 - Kommission/Luxemburg.

191 Ch. von Bar, E. Clive and H. Schulte-Nölke, Principles, Definitions and Model Rules of European Private Law (Draft Common Frame of Reference - DCFR), online edition, 2009; accessible at http://ec.europa.eu/justice/policies/civil/docs/dcfr_outline_edition_en.pdf (accessed 12/ 07/2016); see here, eg Schmidt-Kessel, n 189 above, sec 17 para 47 et seq; H. Eidenmüller, F. Faust, H.Ch. Grigoleit, N. Jansen, G. Wagner and R. Zimmermann, 'Der Gemeinsame Referenzrahmen für das Europäische Privatrecht' JuristenZeitung 2008, 530 et seq; W. Ernst, 'Der «Common Frame of Reference» aus juristischer Sicht' Archiv für die civilistische Praxis 208 (2008), 248 et seq.

192 Proposal for a Regulation of the European Parliament and of the Council on a Common European Sales Law of 11 October 2011, $\operatorname{COM}(2011) 635$ final; here the contributions of the extraordinary meeting of private law lecturers, published in Archiv für die civilistische Praxis 212 (2012) 467-852.

193 Cf $n 108$ above. 


\section{b) Legal Principles of European Private Law}

However, it does not seem futile to extract general legal principles at a European level from European law itself, without having to resort to the law of the Member States. Some examples illustrate this.

In the literature, the attempt is made to develop general legal principles, ${ }^{194}$ such as to discern freedom of contract or contractual fidelity (pacta sunt servanda) from European law. ${ }^{195}$ This is not straightforward, because neither the Treaties nor the Charter of Fundamental Rights directly standardise freedom of contract. ${ }^{196}$ There are only a few judgments that address freedom of contract. ${ }^{197}$ The EU does, though, in Article 119 TFEU acknowledge the 'principle of an open market economy with free competition'; freedom of contract is an essential requirement for this. ${ }^{198}$ Freedom of contract aims to strengthen the internal market by dismantling different legal rules.

194 S. Grundmann (ed), Systembildung und Systemlücken in Kerngebieten des europäischen Privatrechts (Tübingen: Mohr Siebeck, 2000) 1 et seq; K. Riesenhuber, System und Prinzipien des Europäischen Vertragsrechts (Berlin: de Gruyter, 2003) sec 18 with book review Möllers, n 188 above, 1067 et seq; K. Riesenhuber, 'System and Principles of EC Contract Law' 3 European Review of Contract Law 297-322 (2005); generally N. Jansen, 'Dogmatik, Erkenntnis und Theorie im europäischen Privatrecht' Zeitschrift für Europäisches Privatrecht 2005, 750 et seq; Metzger, n 175 above; N. Reich, General Principles of EU Civil Law (Cambridge: intersentia, 2014); J.W. Rutgers and P. Sirena, Rules and Principles in European Law (Cambridge: intersentia, 2015).

195 See, eg K. Riesenhuber, 'Die Inhaltskontrolle von Vereinbarungen über Hauptleistung und Preis im Europäischen Vertragsrecht', in Gedächtnisschrift Wolf (Munich: C H Beck, 2011) 123, 130 with further citations; Heiderhoff, n 174 above, para 230 et seq.

196 Whereas art 2(1) GG standardises freedom of action, and thus also private autonomy, art 16 et seq Charter of Fundamental Rights only contains the protection of freedom to conduct business; critical, therefore F.J. Lindner, 'Fortschritte und Defizite im EU-Grundrechtsschutz, Plädoyer für eine Optimierung der Europäischen Grundrechtecharta’ Zeitschrift für Rechtspolitik 2007, 54, 56: incomplete protection of fundamental rights.

197 ECJ, Judgment of 10 July 1980, 99/79, ECLI:EU:C:1980:193, para 16 - Lancôme speaks of 'legal certainty in contractual matters'.

198 Ch. Schmidt-Leithoff, 'Gedanken über die Privatrechtsordnungen als Grundlage zum EWGVertrag', in Festschrift Rittner (Munich: C H Beck, 1991) 597, 604; O. Mülbert, 'Privatrecht, die EGGrundfreiheiten und der Binnenmarkt' Zeitschrift für das gesamte Handels- und Wirtschaftsrecht (ZHR) 159 (1995) 2, 8; see also art II-1:101 - II-1:103 DCFR. 


\section{Limits of Legal Development at the European Level}

\section{a) Insufficient Justification}

As in German law, legal principles must be developed from the applicable law. When the CJEU elevated the prohibition of age discrimination into a legal principle in the Mangold decision, and invoked, inter alia, the common constitutional traditions, ${ }^{199}$ it was condemned on the basis that such a common tradition did not exist in the Member States at all. ${ }^{200}$

\section{b) Conflicting Legal Principles}

As in German law, a general principle of law can ultimately conflict with a particular outcome. Here again, it is important to take account of the protection of legitimate expectations for the benefit of the citizens. Such a protection of legitimate expectations conflicts with the development of the law for horizontal direct effect of directives. ${ }^{201}$ This must be taken into consideration as part of the development of the law in conformity with the directive. ${ }^{202}$ However, the principle of effective legal protection can restrict the principle of legal certainty and the protection of legitimate expectations. For example, the beneficiary has to refund an unlawfully acquired state aid several years later, although national law provides a one-year period for revocation. ${ }^{203}$

\section{Outlook}

1. The German Civil Code (BGB), characterised by the Pandectists of the $19^{\text {th }}$ Century, ${ }^{204}$ has trained German lawyers in systematic thinking and the associated

\footnotetext{
199 ECJ, Judgment of 22 November 2005, C-144/04, ECLI:EU:C:2005:709, para 75 - Mangold/ Helm.

200 Critical, inter alia, J. Jans, 34 Legal Issues of European Integration 53, 65 (2007); Basedow, n 175 above, 27, 34; J. Basedow, 'Hundert Jahre Rechtsvergleichung' JuristenZeitung 2016, 269, 275 et seq.

201 ECJ, Judgment of 8 October 1987, 80/86, ECLI:EU:C:1987:431, para 10 - Kolpinghuis.

202 ECJ, Judgment of 4 July 2006, C-212/04, ECLI:EU:C:2006:443, para 110 et seq-Adeneler.

203 ECJ, Judgment of 20 March 1997, C-24/95, ECLI:EU:C:1997:163, para 37 et seq and 48 et seqAlcan-reclaiming state aid.

204 To mention, for example A.F.J. Thibaut, System des Pandektenrechts, 3 volumes (5 $5^{\text {th }}$ ed, 1818); G.F. Puchta, Pandekten (5 ${ }^{\text {th }}$ ed, 1850); B. Windscheid, Lehrbuch des Pandektenrechts,
} 
legal doctrine and legal principles until today. In order to further develop the law but also for better understanding, a consolidated doctrine of law with legal principles is required. ${ }^{205}$

Legal principles are to be distinguished from legal concepts and the legal rules.

Legal principles, or the often synonymously used principles of law, are only partially standardised. They are extracted from the legal system as the totality of the written and unwritten legal norms and are more than legal concepts. They are suited to a binding interpretation, and permit a certain generalisation. Legal principles generally claim normative validity and lead to a presumption of conformity. However, they are often not classifiable and require further specification through legal rules or balancing.

Legal concepts, such as justice, expediency, and legal certainty have a high level of abstraction. In consequence, they only constitute (unusable) empty phrases for processing of the case. Legal doctrines are rules with similar factual conditions.

2. In a first step of concretization, legal principles must be justified by the applicable law. In a second step, they are to be substantiated as rules. This often requires inductive and deductive work.

3. Freedom of contract, which can be derived indirectly from various provisions of the BGB, forms an important legal principle in private law. Individual legal doctrines, such as the obligation to contract, price control, or frustration of contract, appear to contradict this principle.

4. Neither a review for correctness, a principle of the social, nor the influence of the constitution can explain the obligation to contract, price control, or frustration of contract. These legal doctrines can rather be justified by the principle of self-determination, which is part of private autonomy applicable to both parties.

5. The CJEU has often developed comparative law principles from the Treaties in a first step. In a second step, these principles must be interpreted independently. This includes European fundamental rights, the claim for State liability, or the principle of effet utile. Legal literature also speaks in favour of the existence of legal principles at the European level (DCFR, CESL).

3 volumes ( $7^{\text {th }}$ ed, 1891); H. Dernburg, Pandekten, 3 volumes ( $4^{\text {th }}$ ed, 1894); F. Regelsberger, Pandekten (1893); R. Zimmermann, in HKK-BGB, n 37 above, with sec 1 para 6 et seq.

205 Legal doctrine is vividly compared with grammar, without which language, here the legal norms, cannot be understood, M. Herberger, Dogmatik (Frankfurter/Main: Klostermann, 1981) 37 et seq, 74 et seq, 119, 257 et seq with extensive references to Roman law; Jansen, n 194 above, 754. 